
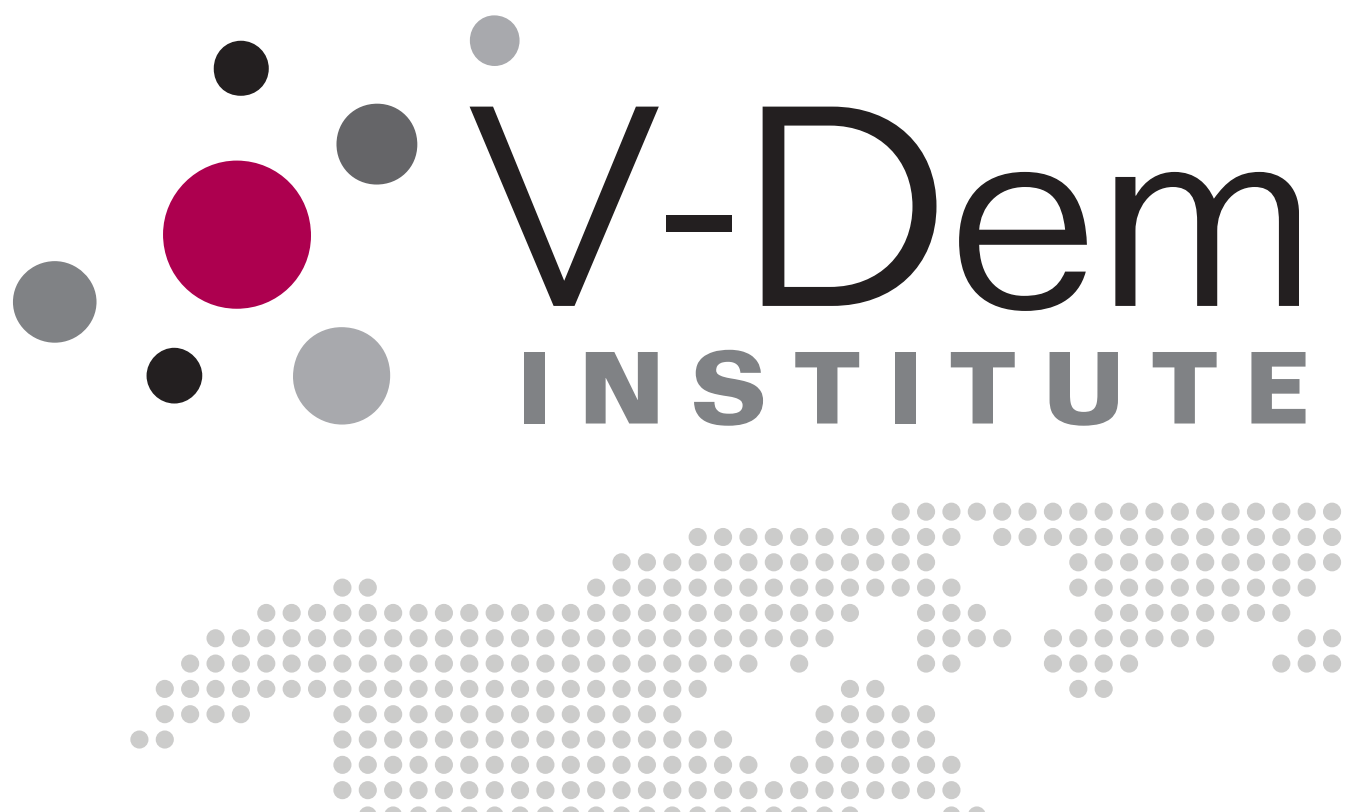

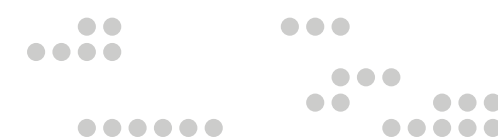

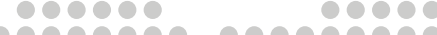

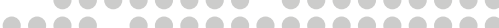
00000000000000000

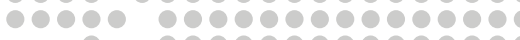
1.0 0000

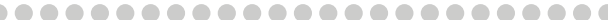

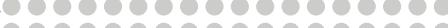

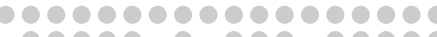

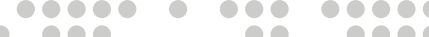

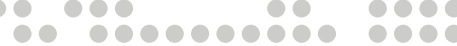

Reassessing the Democratic Peace: A Novel Test Based on the Varieties of Democracy Data

Håvard Hegre, Michael Bernhard, Jan Teorell

100009080

0090900

100000

090000

10000

000

100

10

10

O

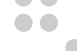

March 2018

000000000

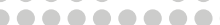

190000000

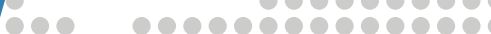

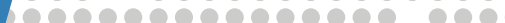
1000000000000000

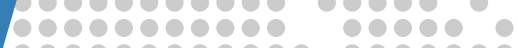

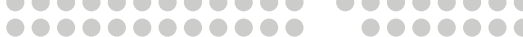

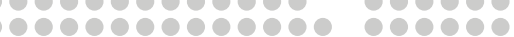
 000000000000000 \begin{tabular}{l}
10000000000000000000 \\
\hline
\end{tabular} 10000000000000000000

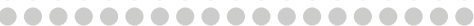

-

10000000000000

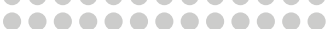

00000000000

00000000000

0

ö000000000

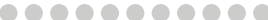

60000000000

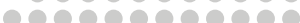
-

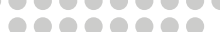

000000000

10809000

200800

000000

1000

000 
Varieties of Democracy (V-Dem) is a new approach to conceptualization and measurement of democracy. It is co-hosted by the University of Gothenburg and University of Notre Dame. With a V-Dem Institute at University of Gothenburg with almost ten staff, and a project team across the world with four Principal Investigators, fifteen Project Managers (PMs), 30+ Regional Managers, 170 Country Coordinators, Research Assistants, and 2,500 Country Experts, the $\mathrm{V}$-Dem project is one of the largest ever social science research-oriented data collection programs.

Please address comments and/or queries for information to:

V-Dem Institute

Department of Political Science

University of Gothenburg

Sprängkullsgatan 19, PO Box 711

SE 40530 Gothenburg

Sweden

E-mail: contact@v-dem.net

V-Dem Working Papers are available in electronic format at www.v-dem.net.

Copyright (C) 2018 by authors. All rights reserved. 


\title{
Reassessing the Democratic Peace: A Novel Test Based on the Varieties of Democracy Data*
}

\author{
Håvard Hegre \\ Professor \\ Department of Peace and Conflict Research \\ Uppsala University \\ Michael Bernhard \\ Miriam Ehrlich Chair in Political Science \\ Department of Political Science \\ University of Florida \\ Jan Teorell \\ Professor of Political Science \\ Department of Political Science \\ Lund University
}

\footnotetext{
* Earlier versions of the paper has been presented to the 2016 convention of the International Studies Association, the 2016 Swedish National Conference on Peace and Conflict Research, and the 2016 convention of the American Political Science Association. Thanks to Charity Butcher, Stephen Marr, Nils Petter Gleditsch, and Michael J. Reese for comments on earlier versions of the paper, and to Jennifer C. Boylan, Ryan P. Whittingham, Gudlaug Olafsdottir, and Kristina Petrova for excellent research assistance. The research has been funded by the Research Council of Norway, project 217995/V10, the University of Florida Foundation in support of the Raymond and Miriam Ehrlich Chair, Riksbankens Jubileumsfond, grant P16-0124:1, and the Swedish Research Council, grant 2012-5562. Jan Teorell also wishes to acknowledge support from the Wenner-Gren Foundation and the Fernand Braudel Senior Fellowship at the European University Institute, Florence, which made it possible for him to work on this paper.
} 


\section{Abstract}

The democratic peace is one of the most robust findings in international relations. Yet it suffers from two important limitations. First, even those who fully embrace the democratic peace have difficulty precisely identifying which facet of democracy drives the result. Second, the vast majority of studies have relied on a single measure of democracy - the Polity index. This paper reassesses interstate conflict on several new measures of democracy and their disaggregated components from the Varieties of Democracy project in a global sample of 173 countries from 1900-2010 (www.v-dem.net). We theorize three distinct mechanisms of constraint that may explain why some countries do not engage in military conflict with each other: formal vertical (e.g. elections), informal vertical (e.g. civil society activism), and horizontal accountability (e.g. interbranch constraint on the executive). We find that the formal vertical channels of accountability provided by elections are not as crucial as horizontal constraint and the informal vertical accountability provided by a strong civil society. 


\section{Introduction}

The democratic peace has proved to be one of the most influential and durable findings in the history of international relations, if not political science as a whole. The foundational studies by Bremer (1992) and Maoz and Russett (1993) have both netted over 1000 citations on Google Scholar. ${ }^{1}$ And while some alternative explanations have been offered such as the 'capitalist peace' (Gartzke, 2007; Mousseau, 2000; 2009; 2013), the 'territorial peace' (Gibler 2010), or 'political similarity' (Bennett, 2006; Raknerud and Hegre, 1997; Peceny, Beer and Sanchez-Terry, 2002; Werner, 2000), such work has done little overall to undermine the broad acceptance of the basic empirical regularity. If there is any substantial weakness in the extensive literature on the subject, it is not belief in the empirical finding itself, so much as providing a fully convincing causal logic to explain it (Rosato, 2003). What is it about democracy that makes it less likely to engage in conflict with other democracies? This daunting puzzle still remains subject to a lively and inconclusive debate (Hegre, 2014).

In this paper, we reopen and advance this debate by arguing that several different forms of constraint on power holders help to explain why democracies are less likely to enter into conflict with each other. In doing so, we also advance the democratic peace agenda on the measurement side. Whereas the vast majority of studies have relied on Polity to capture the degree of democracy among states, we propose a test with new data from the Varieties of Democracy (V-Dem) project, which we argue has both better concept-measurement consistency and also allow for disaggregation of the composite concept of 'democracy.' V-Dem contains a large number of disaggregated democracy indicators have been collected from more than 2,600 country experts from 173 countries across the globe from 1900-2010. Using these, we show that three different mechanisms of accountability - horizontal, formal vertical, and informal vertical all restrain democracies from fighting with each other. Horizontal accountability refers to the ability of other state institutions to constrain the actions of the executive. In democracies, formal vertical accountability is provided by the incumbent's desire to remain in power, and thus an unwillingness to alienate the electorate in anticipation of the next election. Informal vertical accountability is provided by the ability of organized actors in civil society to inflict audience costs on the executive in-between elections, and to mobilize in support of opponents during elections. When pitting the three mechanisms of accountability against each other, we find the

1 https://scholar.google.com/scholar?cites $=17583492336353768752 \&$ as sdt $=40005 \&$ sciodt $=0,10 \& h l=e n$ and https://scholar.google.com/scholar?cites $=3827946356775670036 \&$ as sdt $=40005 \&$ sciodt $=0,10 \& h l=$ en $\quad$ (retrieved February 17, 2016). 
weakest support for the formal vertical one. The democratic peace effect thus seems less to be a function of electoral pressures on executive incumbents than on the ability of other state institutions, as well as civil society actors, to constrain the executive.

This has important implications for current theories of conflict initiation. Most importantly, it moves the state of theory beyond the traditional preoccupation with pitting "normative" against "structural" explanations for the democratic peace (Maoz and Russett, 1993). We argue that since structural constraints will have normative (or cultural) implications, these two versions of theory cannot be fruitfully contrasted with each other. The way forward is instead to disentangle what structural impediments (with probable downstream "normative" ramifications) most consistently constrain states from engaging in military conflict with each other. We advance this particular theoretical research agenda by moving beyond models solely concentrated on electoral accountability (e.g. Bueno de Mesquita et al. 2003) or executive constraints (e.g., Choi 2010) and instead examining both formal and informal paths of accountability, including interest advocacy practiced by civil society organizations.

\section{Retheorizing the mechanisms behind the democratic peace}

\subsection{Prominent explanations of the democratic peace}

The most common explanations for the democratic peace are the 'normative' and the 'structural' (MaOz and Russett, 1993). ${ }^{2}$ Normative explanations hold that 'the culture, perceptions, and practices that permit compromise and the peaceful resolution of conflicts without the threat of violence within countries come to apply across national boundaries toward other democratic countries as well' (Ember, Ember and Russett, 1992, 576). States 'externalize' the domestic norms that encourage compromise solutions and reciprocity, and treat politics as more than a zero-sum game where losers are eliminated from future contests (Weart, 1998). 'People within a democracy perceive themselves as autonomous, self-governing people who share norms of live and let live; they respect the right to self-determination of those who are perceived as self-governing and hence not led easily into aggressive foreign policies by a self-serving elite' (Ember, Ember and Russett, 1992, 576).

\footnotetext{
2 Other explanations are reviewed in Hegre (2014). These include the argument that democracies are better able to mobilize resources in war (Reiter and Stam, 1998), or to form alliances (Doyle, 1986), or that they have joint interests in international relations (Gartzke, 1998). The V-Dem dataset is not well suited to shed more light on these particular arguments.
} 
Structural explanations start from the assumption that international action in a democratic political system [except in emergencies] requires the mobilization of both general public opinion and of a variety of institutions that make up the system of government, such as the legislature, the political bureaucracies, and key interest groups' (Maoz and Russett, 1993, 626). Democratic leaders, then, must ensure that the interests of citizens and powerful organizations are taken into account. If they circumvent these constraints, democratic political leaders will face the prospect of removal from office (Bueno de Mesquita, Siverson and Woller, 1992; Bueno de Mesquita et al., 1999). Debate, moreover, is public and decision-making is formalized, so information on the real costs of war is likely to enter the decision calculus. '[Democratic leaders] will not fear attack by another democracy. They will also know that institutional constraints, and the need for public debate in the other democracy, will prevent a surprise attack and so eliminate their own incentives to launch a preemptive strike" (Ember, Ember and Russett, 1992, 576-577). ${ }^{3}$

Another insight related to such structural explanations is the ability of democracies to signal their intentions. Why is it that states are not able to agree to a solution that reflects the distribution of power and the actors' intention or 'resolve', without incurring the costs of war (Fearon, 1995)? One answer is that if crisis escalation is not very costly, both parties have an incentive to exaggerate their power or resolve, mobilize, and then to back down when they realize the bluff is discovered. Fearon (1994) argues that audience costs - the costs that a leader suffers when backing down - lock leaders into their positions, increasing reputational costs if they are caught bluffing. He argues that democracies have higher audience costs and are thus more likely to credibly commit to policies that signal their intentions while avoiding the kind of behavior more likely to escalate a crisis. ${ }^{4}$ We find the logic of his argument compelling with regard to why the democratic peace is dyadic and not monadic.

Although the behavioral mechanisms implied in the constraints and signaling explanations are somewhat different, they both rest on the idea that democracies have a set of institutionalized mechanisms through which leaders are held accountable for their actions (Rosato, 2003). Both leave considerable room to further specify the exact mechanisms that promote accountability. From the perspective of measurement, normative factors are harder to operationalize, especially for comprehensive global country-year samples for long periods of

\footnotetext{
3 Also see Schweller (1992).

4 Choi (2010) is one recent example of empirical support for the constraints explanation. Making use of various empirical strategies to distinguish the explanations, Schultz (1999) and Prins (2003) find stronger support for the signaling argument than for the constraints explanation. Weeks (2008) builds on this argument by showing that single-party regimes also exhibit behavior in line with a signaling argument. Downes and Sechser (2012), Snyder and Borghard (2011), and Trachtenberg (2012), on the other hand, find little empirical evidence for the audience cost argument.
} 
time. It is maddeningly difficult as well to distinguish normative from structural explanations empirically because 'norms of reciprocation and compromise' over time become formalized as institutions, blurring the distinction between the two. The norms that arguably explain the democratic peace, according to $\mathrm{MaOz}$ and Russett, are embedded in 'regulated political competition' (1993, 625). Thus we both think it unlikely that there is anything like direct normative explanations disembodied from institutions. Hence, exploring what types of 'regulated political competition' are associated with interstate peace can be argued to represent institutionally embedded norms. For this reason, our contribution will focus on structural constraints, moving them out of the realm of theory, and using the depth of the indicators in the Variety of Democracy dataset to evaluate different causal pathways.

\subsection{Unpacking Constraint: Paths of Accountability}

We examine both horizontal and vertical accountability, critical components of democratic practice, brought to the fore in the study of democratic regime change by O'Donnell (1998). We also move beyond his understanding by examining both formal and informal paths of accountability. We understand the primary mechanism of accountability to be the ability of actors to sanction others in concrete relations of power. Like Lindberg (2013) we understand 'sanction' in the full range of its positive and negative meanings in English, both to impose costs that can constrain unwanted behavior and to authorize actions in line with the rules of the game. Schedler (1999) adds to our understanding by not only emphasizing the ability to punish governmental officials who overstep their authority, but also the ability to call them to account to oblige them to inform the public about their activities and to justify them. Thus, even those exercising authority completely under a rigorous system of rule of law face the prospect of incurring political costs for the policies that they pursue.

We identify three principal paths of accountability: through the institutionalized mechanism of elections by which incumbents may be removed from power (formal vertical); through the checks and balances between different state institutions (formal horizontal); and through the costs imposed by the protests, publicity, and withdrawal of support provided by organized groups in civil society (informal vertical).

\section{Formal vertical accountability by electoral means}

In turning to vertical accountability we begin with the formal dimension, how the reiterated regular and competitive election of leaders creates responsiveness to the concerns of the 
citizenry. Immanuel Kant (1795/1991) argued that the citizens of a (democratic) republic would hesitate before plunging into a war, for 'this would mean calling down on themselves all the miseries of war' (p. 100). Insensitivity to citizens' preferences leads to sanctions by voters in the next round of elections and this promotes the accountability of elected officials to the electorate. The logic of this form of accountability is captured by Przeworski, Stokes and Manin (1999, 10): Governments are 'accountable' if citizens can discern representative from unrepresentative governments and can sanction them appropriately, retaining in office those incumbents who perform well and ousting from office those who do not. An 'accountability mechanism' is thus a map from the outcomes of actions (including messages that explain those actions) of public officials to sanctions by citizens. Elections are a 'contingent renewal' accountability mechanism, where the sanctions are to extend or not to extend the government's tenure.

This mechanism is a product of the relationship between leaders and the electorate. We use our conceptualization of electoral democracy to examine this potential causal linkage, drawing on a rich strand of democratic theory evolving from Schumpeter's (2003/1942) classic definition, and, with the important addition of suffrage, more recently Munck's (2009) minimalist conception of democracy (also see Boix, Miller and Rosato 2012). According to this conceptualization, electoral democracy embodies the core value of making rulers responsive to citizens through competition for the approval of a broad electorate during periodic elections, including minimal political rights (most importantly suffrage and the freedom to form multiple political parties) seen as prerequisites to the holding of meaningful elections. ${ }^{6}$

The institutional explanations of the democratic peace most commonly refer to this electoral component or some version of it. Leaders that are perceived to conduct risky and unsuccessful international policies are either not elected in the first place, or removed after failure by the voters (Bueno de Mesquita, Siverson and Woller, 1992; Fearon, 1994). The ability of voters to hold leaders accountable is thus key. This requires that 'there are regular opportunities for democratic publics to remove elites who have not acted in their interests' (Rosato, 2003). Since

\footnotetext{
${ }^{5}$ Kant (1795/1991) is the standard reference, but several other enlightenment theorists precede Kant in arguing that states founded on democratic principles must also be against war (Gates, Knutsen and Moses, 1996, 6-7). For a critique of the interpretation that Kant was a forerunner of modern democratic peace theory, see Jahn (2005); Franceschet (2000).

6 Although famous for encompassing both inclusion and contestation, Dahl's (1971) influential model of 'polyarchy' is a more maximalist version of electoral democracy that also brings in more extensive political rights and civil liberties (most importantly freedom of organization, even going beyond multi-party elections, and freedom of expression). In our effort to tease out what specific mechanisms help explain the democratic peace, we do not rely on this broader conception in this paper but instead assess the more minimalist conception, both with and without suffrage (see below), and with the separate addition of media freedom (the latter however as a feature of horizontal accountability).
} 
the electoral mechanism has received the most attention in efforts to explain the democratic peace, we expect to replicate the democratic peace finding when operationalizing this conception of democracy.

V-Dem, moreover, for the first time allows for a systematic investigation of what component parts of electoral democracy are most important for explaining this outcome. We have strong theoretical expectations in this regard. Knowing that universal suffrage, as well as the introduction of nominal executive elections or presidential plebiscites, have been widely practiced in single-party and even personalist dictatorships with rigged elections and strong state repression (Hermet, Rose, and Rouquie 1978), we deduce that only those elements present in democracy and absent in plecibiscitary dictatorship should explain the democratic peace namely free and fair elections under multiparty competition.

\section{Formal horizontal accountability through institutional checks and balances}

The second mechanism we explore is horizontal accountability. According to O'Donnell (1998, 117): "This kind of accountability depends on the existence of state agencies that are legally empowered - and factually willing and able - to take actions ranging from routine oversight to criminal sanctions or impeachment in relation to possibly unlawful actions or omissions by other agencies of the state.' Merkel $(2004,41)$ elaborates on the positive aspects of this form of accountability: 'elected authorities are surveyed by a network of relatively autonomous institutions and may be pinned down to constitutionally defined lawful action'. He understands this as a set of reciprocal checks between the executive, legislature, and judicial organs that both respect the constitutional responsibilities of each but which constrains the actions of each to those which they are lawfully empowered to discharge. The existence of horizontal accountability renders democracy into a self-equilibrating system where actors are compelled to abide by the rules of the game due to the potential sanctions that other players can levy, either withholding permission or imposing costs. This is primarily achieved through effective legislative and judicial checks on executive power.

This conception featured in Doyle's $(1983 a ; 1983 b)$ highly influential argument about the 'liberal peace.' The 'liberal' component has also often been invoked in other studies attempting to explain the democratic peace (Ember, Ember and Russett, 1992). The mechanism most clearly articulated seems to be that strong constraints on the executive ensure that decision-making takes time and that the real costs of the policies are (at least better) taken into account. This mechanism is elaborated on in Choi (2010)'s application of legislative veto-player theory to the understanding of international conflict. He builds on Tsebelis' insight that dense networks of 
veto players enhance policy stability, thus impeding rash decisions to enter into conflict (1995, 293). Such liberal-peace arguments imply that it is horizontal accountability between key governmental institutions that matters for peace.

Horizontal accountability is finally also said to be promoted by the media because of its indispensability in enabling other actors to track and understand the actions of those in power (Rosato, 2003). This is because the media are a primary source of information for voters at election time as well as for citizens engaged in civil society organizations. It is also an alternative information source for those exercising countervailing power in the state. Thus responding to the flow of public information is a major concern for political incumbents. The degree to which press and media freedom is impeded, makes it more difficult to exercise constraint over political leaders and other decision-makers or even sometimes to have a full understanding of the actions they are taking (Voltmer, 2009; Hutchings, 2005; Semetko 2009).

\section{Informal vertical accountability by civic action}

The third mechanism we highlight is non-electoral vertical accountability, a pathway that has not received much attention in explanations of the democratic peace. Whereas formal accountability is exercised through elections or in their anticipation, there are mechanisms of citizen engagement that can impose audience costs on leaders in informal ways between elections. Here we draw inspiration from participatory notions of democracy, which received considerable attention in democratic theory particularly in the 1970s and 1980s (Pateman, 1970; Macpherson, 1977; Barber, 1984; Gould, 1988). This tradition primarily emphasizes citizen engagement and non-electoral forms of political participation through civil-society organizations (both advocacy and protest).

The formal vertical accountability provided by regular elections is uneven and periodic; it is enhanced in the final stages of the electoral cycle when incumbents and challengers vie for power. As Merkel notes $(2004,38)$ : 'At most, voters only have continuing control in so far as a circumspect politician, aiming to get re-elected, might align their manner of governing to the wishes of the voters.' Here we expand notions of vertical accountability into the informal realm. A number of authors conceive of the kind of interest advocacy practiced by civil society organizations as a more direct form of representation which can serve as an alternative path of accountability that supplements or in some instances supplants elected representation (Schmitter, 1992; Peruzzotti, 2007; Fung and Wright, 2003; Dalton, Scarrow and Cain, 2003; Chalmers, Martin and Pister, 1997; Houtzager and Lavalle, 2010). 
The widespread exclusion of the participatory component from the democratic peace literature omits one of two essential pathways by which democratic publics inflict audience costs on their leaders. Powerful civil society organizations provide citizens with other means to constrain leaders and the political establishment. Smulovitz and Peruzzotti $(2000,153)$ outline the mechanisms by which civil society organizations can promote accountability. These include protest mobilization against unpopular actions and policies, citizen-based monitoring and oversight of government agencies and officials, activist litigation in the courts, as well as alternative sources of publicity about government actions. Ekiert and Kubik $(1999,9)$ go far to argue that the contentious action of civil society can be essential to establishing accountability where there are defects with other institutional domains such as party systems. In cases where elected officials are constrained by either secrecy or purposively practice it or ignore public opinion, popular mobilization may provide another institutional means to constrain leaders by increasing their concerns about audience costs (Fearon, 1994).

Table 1 summarizes the ways in which we argue that our three different forms of accountability tap into different mechanisms that could explain the connection between democracy and conflict.

Table 1: Mechanisms of Democratic Accountability and How They Potentially Explain the Democratic Peace

Mechanism

1. Formal Vertical Accountability via Elections

2. Horizontal Accountability via Countervailing Powers

3. Informal Vertical Accountability via Civil Society Activism

\section{Causal Pathway}

Elected executive under conditions of clean, multiparty elections, and universal suffrage $\rightarrow$ government responsiveness to popular preferences via potential audience costs

Judicial and legislative constraints on the executive under conditions of media freedom $\rightarrow$ constraints on arbitrary exercise of executive power

Activism by civil society organizations (advocacy, protest, monitoring) $\rightarrow$ government responsiveness to popular preferences via potential audience costs 


\section{Research design}

Our research design is built on Hegre, Oneal and Russett (2010) that again are based on earlier studies of the democratic peace. Formulating the dyadic nature of the democratic peace is not straightforward. Most studies use Dixon's (1994) 'weak link' assumption, and measure the relevant variable for the 'least constrained' country in the dyad. This is done on a variable-by-variable basis - a dyad is coded with the democracy score for the least democratic country in the dyad and with the trade-dependence score for the least trade-dependent of the two. As argued in Hegre (2009, 30), there is a fundamental problem with the weak-link procedure. In many cases, one of the two countries is the least democratic and the other of them the least trade-dependent. Which of the two countries is then the least constrained overall?

We instead use a variation of the weak-link procedure proposed in Hegre (2008) that assumes that the strongest country in the dyad (in terms of military capabilities) always is the one that is 'least constrained'. We refer to this country as country $i$ and the weaker as $j$. Here, we enter the democracy score for the stronger country in the pair (called country $\imath$ ), that of the weaker country (j), and the multiplicative interaction term between the two (ij). If the dyadic democratic peace holds, the interaction term should be negative - the risk of interstate militarized conflict decreases as both countries become more democratic. We use similar constructions for the control variables in the models. ${ }^{7}$

\subsection{Dependent variable: Fatal MIDs}

The dependent variable is the onset of 'fatal MIDs' - militarized interstate disputes that lead to the death of at least one person. We use the MID v4.1 version (Palmer et al., 2015) to extend the dyadic MID dataset (Maoz, 2005) up to 2010. In combination with the V-Dem data, this allows us to study the 1900-2010 time period.

\footnotetext{
7 To ascertain that our results are robust to alternative specifications, we also in report in Appendix Table A-5 results with the traditional weak-link formulation to reproduce the main results (using the interaction specification for the control variables). The substantial conclusions from these models are similar to the ones from our preferred specification. AIC scores in the 'traditional' specification are in general much higher than the corresponding scores in our preferred specification.
} 


\subsection{Main Independent Variables}

The vast majority of studies on the democratic peace since Bremer (1992) have relied on the Polity dataset to operationalize the concept of democracy. ${ }^{8}$ There are many good reasons for this choice. Among the major datasets that measure democracy, Polity is the most extensive in terms of its coverage across time. In conjunction with the COW data this allows findings to be based on the population of states (save for micro-states) in the global system from the post-Napoleonic period to the present.

Polity has been to some extent amenable to disaggregating certain aspects of democracy to examine which of its properties are responsible for the pacific nature of democratic dyads. Choi (2013) for example has used it effectively to show that one prominent component, executive constraint (xconst), is a potential cause. ${ }^{9}$ However, Polity is not particularly amenable to more fine-grained disaggregation that will allow us to pinpoint the ways in which political accountability works to enhance peace.

This is in part due to the fact that Eckstein and Gurr did not initially set out to explicitly understand and measure democracy, but patterns of authority (Eckstein and Gurr, 1975). ${ }^{10}$ Despite the conceptual origins of the project, Gurr was able to adapt the taxonomy to distinguish the three classic Polity-based regime types - democracy, anocracy and autocracy. However, his conceptualization of democracy at that stage - 'the presence of multiple institutionalized centers of power, some of which are open to widespread citizen participation' stands as relatively underspecified from the perspective of modern comparative politics (Gurr, 1974, 1487). This contrasts with autocracy, which monopolizes power in one center and anocracy, which is under-institutionalized.

This work was further elaborated and validated in Jaggers and Gurr (1995) where they specify three dimensions of democracy: 1) 'the presence of institutions and procedures through which citizens can express effective preferences about alternative policies and leaders,' 2) 'institutionalized constraints on the exercise of executive power', and 3) 'guarantee of civil liberties to all citizens in their daily lives and actors of political participation' (p. 471). Yet there is

\footnotetext{
8 Several earlier studies relied on other, dichotomous indicators of democracy (e.g. Babst, 1964; Small and Singer, 1976; Doyle, 1986), and Rummel (1983) used the Freedom House data.

9 Choi argues that we need to look at the impact of structural and normative factors, and is most interested in the interaction between executive constraint as the former and rule of law as the latter. We would see both of these as properties of democratic institutions and structural. In his base model executive constraint is also significant on its own (p. 267).

10 This original theoretical work on the project yielded a 479-page volume in which the term 'democracy' is referenced in the index on thirteen pages, whereas 'authority' merits references on over 200 pages (Eckstein and Gurr, 1975).
} 
little discussion of how the five indicators used in tabulating the 21-point polity scores match up to these dimensions. Clearly effective expression of preferences is related to how competitive and regulated political participation is (five points and two points respectively), but they are not coterminous. There is a preponderance of information about the chief executive here competitiveness of recruitment (four points), openness of recruitment (two points), and constraints on the chief executive (seven points), perhaps even too much, as Gleditsch and Ward (1997) have pointed out. Finally, there are no direct measures of civil liberties here at all.

In this article, we instead apply the framework of the V-Dem project to improve our understanding of various ways democratic political systems allow both other members of the elite embedded in countervailing centers of institutional power and the citizenry to constrain decision makers. We disaggregate what is meant by constraint using the concept of accountability as measured by the Varieties of Democracy dataset (Coppedge et al., 2011, 2016b; Lindberg et al., 2014). While not as extensive over time as Polity, it covers 173 different countries since 1900 and has an unprecedented conceptual depth that allows for democracy to be considered as a variety of aggregates and to examine the effect of its component parts.

The V-Dem data are collected from country experts, mostly academics from each country, through questions with well-defined response categories or measurement scales. These experts are recruited based on their academic or other credentials as field experts in the area they code, as well as on their seriousness of purpose and impartiality. The questionnaire is subdivided into 11 different areas of expertise, and most experts code a cluster of three such areas. The target is that at least 5 experts rate each indicator for each country and year going back to 1900. This means that more than 2,600 experts in all have participated in gathering the data. The individual-level expert ratings are aggregated to country-year scores using a Bayesian item response theory (IRT) measurement model (see Pemstein et al, 2015). This model produces a latent variable estimate for each expert-coded indicator after taking varying rater thresholds and coder reliability (precision) into account. Since most coders rate one country only in areas based on their expertise, V-Dem also utilizes 'lateral' coders who rate multiple countries for a limited time period, as well as 'bridge' coders who code the full time series for more than one country. Essentially, this mitigates the potential incomparability of coders' thresholds and enhances cross-national comparability (Coppedge et al., 2016c).

In this paper we will primarily draw on five different indices of constraint, one for vertical electoral accountability (also decomposed into one sub-index and one indicator), three for horizontal, and one for vertical non-electoral accountability. Before presenting these, we would like to highlight two inferential problems that will limit our ability to draw firm conclusions 
about the relative importance of different mechanisms of constraint. The first is the fact, also illustrated below, that all indices are modestly to strongly inter-correlated. Due to multicollinearity, it is thus difficult to discern the effect of one of them while controlling for the others. Second, lacking a model for how the accountability mechanisms might affect each other, we can only base our inferences on estimates of direct effects. To the extent that some constraints (such as electoral democracy) are the prime movers of all the others, their indirect effects will thus be omitted.

\section{Electoral accountability}

Following Munck (2009), this is an index of electoral accountability based on four components: 1) an elected executive (v2x_accex, a multiplicative index based on 12 indicators), 2) clean elections (v2xel_frefair, a Bayesian Factor Analysis (BFA) index based on 8 indicators), 3) multiparty elections (v2x_multiparty, a BFA index based on four indicators), and 4) universal suffrage (v2x_suffr, which is a single indicator). ${ }^{11}$ To capture the notion that each of these components is a necessary condition, and that the overall level of electoral accountability works as a chain defined by its weakest link, the four components are aggregated into an overall index through multiplication (v2x_munck). In order to tease out the extent to which suffrage plays an independent role in explaining the democratic peace, we also rely on an index only based on only the first three components. This index more closely follows Schumpeter's (2003/1942) influential minimalist definition of democracy, where suffrage was never explicitly made part of the definition. ${ }^{12}$ When this Schumpeterian index of electoral accountability is used, we control separately for the extension of the suffrage.

We construct three variables from the electoral accountability index: Electoral accountability is the index for the stronger country in the dyad, Electoral accountability $j$ that for the weaker. Electoral accountability $_{i j}$ is the product of Electoral accountability $y_{i}$ and Electoral accountability. All indices are scaled to range from 0 to 1 . We make similar constructions from the other country-level variables.

\footnotetext{
11 See the V-Dem codebook (Coppedge et al., 2016a) for detailed information on all indicators referred to here.

12 Although not a binary indicator, this even more minimalist Schumpeterian conception of electoral democracy is conceptually very similar to the Przeworski et al. (2000) measure of democracy.
} 


\section{Legislative constraints on the executive}

This and the following index measure the existence of effective checks that limit the use of executive power. In terms of the V-Dem indicators, legislative constraints on the executive (v2x_legcon) is based on the point estimates from a Bayesian factor analysis model of indicators tapping into (a) the extent to which the legislature questions officials in practice, (b) exercises executive oversight, (c) investigates the executive in practice, and (d) whether legislature opposition are able to exercise oversight and investigatory functions against the wishes of the governing party or coalition. ${ }^{13}$

\section{Judicial constraints on the executive}

This index (v2x_jucon) is formed by taking the point estimates from a Bayesian factor analysis model of indicators tapping into (a) whether the executive respects the constitution, and whether the executive complies with important decisions of both (b) the high court and (c) lower courts with which it disagrees; as well as how often the (d) high court and (e) lower courts make decisions that merely reflect government wishes regardless of its sincere view of the legal record (judicial independence). To ameliorate multicollinearity concerns, we also include a more general index of executive constraints by simply taking the average of the legislative and judicial constrains indices (v2x_execon).

\section{Media freedom}

This index (v2x_mefree) is formed by taking the first principle component of the indicators tapping into the extent of (a) print/broadcast censorship effort, (b) harassment of journalists, (c) media bias against opposition parties, (d) media self-censorship when reporting on issues that the government considers politically sensitive, (e) criticism of the government among the major print and broadcast outlets, and ( $\mathrm{f}$ ) how wide a range of political perspectives the major print and broadcast media represent.

\section{Civil society participation}

Civil society organizations (CSOs) include, but are by no means limited to, interest groups, labor unions, spiritual organizations (if they are engaged in civic or political activities), social

13 If $v 2 x \_$legcon is missing information we assume the legislature is missing entirely and set v2x_legcon to 0 . 
movements, professional associations, charities, and other non-governmental organizations. The index is formed by taking the point estimates from a Bayesian factor analysis model of the indicators tapping into (a) whether civil society influences the legislative candidate nomination within party organization through decentralization or party primaries, (b) whether major CSOs are routinely consulted by policymakers, (c) how extensive is the involvement of citizens in the network of CSOs, and (d) CSO women's participation. ${ }^{14}$

\section{Mapping constraint}

The five indicators of constraint are highly correlated with each other. For the year 2010, the indicators are correlated at 0.77 or higher (see Appendix Figure A-1). ${ }^{15}$ In 2010, the civil society participation and media freedom indices are somewhat distinct from the three formal indices of constraint. The scatterplots in Figure 1 show how the legislative constraint (left) and civil society participation (right) relate to the electoral accountability index.

Figure 1. Scatterplot of legislative constraint index vs. electoral accountability index (left) and civil society participation index vs. electoral accountability index (right), 2010
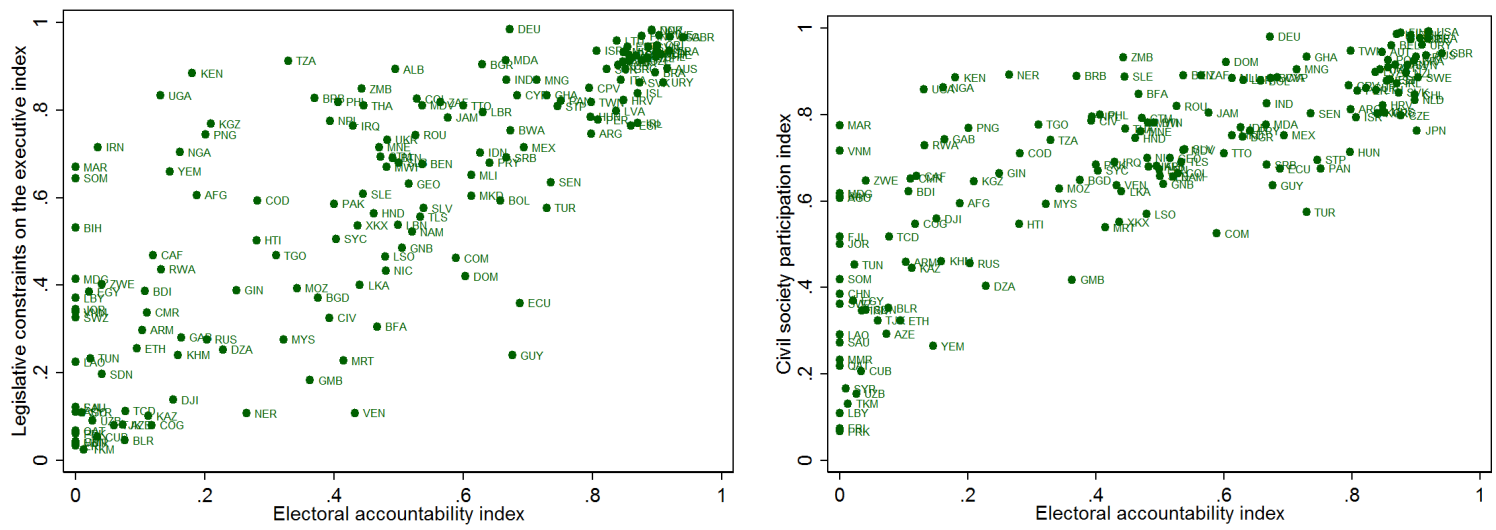

Longstanding, consolidated democracies typically have high values for all these indicators, such as Great Britain (GBR) or Italy (ITA). Likewise, clearly authoritarian regimes such as Cuba (CUB) or Qatar (QAT) have low values for each. A large number of emerging democracies display much more heterogeneous patterns of constraint. Countries like Venezuela (VEN), Guyana (GUY), and Ecuador (ECU) have weak legislative constraints on the executive

14 If v2x_cspart is missing information we imputed the value based on the v2cscnsult, v2csprtcpt, and v2csgender indicators.

15 For earlier years, these correlations are considerably lower. 
compared to electoral accountability. Other countries, such as Iran (IRN), Kenya (KEN), and Tanzania (TAZ) have strong legislative checks on executive power. Civil society participation differs from electoral accountability following a different pattern. It is clearly weakest in those political systems that have almost no electoral accountability, such as in North Korea (PRK) and Turkmenistan (TKM). Non-competitive electoral systems, such as Morocco (MAR) and Vietnam (VNM), are less repressive of civil society. Among those countries with higher levels of electoral accountability there is considerable variation in how participatory civil society is. Ghana (GHA), for instance, scores much higher than Turkey (TUR) in 2010.

Figure 2. Global trends in the five indices of constraint and the V-Dem Polyarchy index, 1900-2012. Non-weighted country averages.

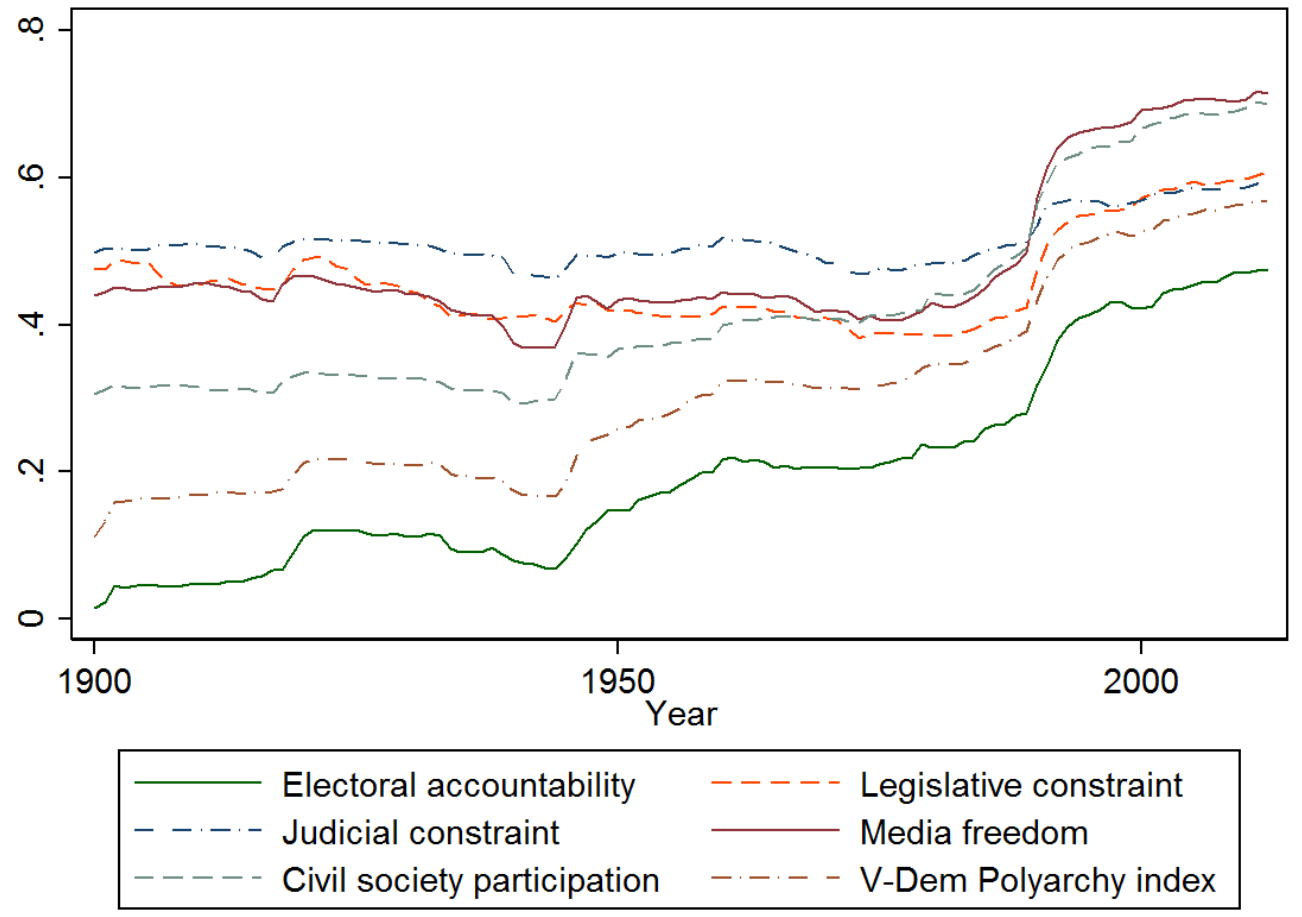

Figure 2 shows global trends in the indices of constraint, demonstrating another dimension of differences between them. The (unweighted) global average for the electoral accountability index (v2x_munck) increased steadily from close to 0 to about 0.4 as political liberties were extended in most countries in the world. The civil society participation index has also increased steadily throughout the $20^{\text {th }}$ century and beyond. The indices of horizontal constraints (legislative and judicial), on the other hand have changed little from 1900 up to the collapse of the Soviet Union 
in $1990 .{ }^{16}$ All indices increased markedly after the end of the Cold war, and have increased in parallel over the past 25 years. If the democratic peace depends mostly on the vertical accountability mechanisms, Figure 2 indicates that it has strengthened considerably over the past century. If it draws strength mainly from the horizontal accountability mechanism, this deepening mainly occurred after the Cold war.

\subsection{Other Variables}

Polity: We also present results using democracy data from the Polity dataset (Jaggers and Gurr, 1995; Marshall, n.d.) for comparison. The V-Dem Polyarchy index and the Polity2 index are highly correlated (at about 0.84 ), but differ in some important respects. In general, the V-Dem index displays a stronger increasing trend over time than Polity, in part since it reflects the extension of suffrage much better than Polity. ${ }^{17}$

Military capabilities: The COW military capabilities index (Singer, Bremer and Stuckey, 1972) is based on data on states' total population, urban population, energy consumption, iron and steel production, military expenditures, and size of the armed forces. The COW project calculated each state's share of the world's total for each of these sub-indices. The CINC index is constructed as the unweighted average of each of these shares. The theoretical range for the index is $[0,1]$. In log form, the capabilities index $\ln M_{i}$ ranges from -11.5 to -0.957 .

Population size: The population variables $\ln P_{i j}$ are the natural $\log$ of total population in thousands for countries $i$ and $j$. The variable originates from the Correlates of War military capabilities dataset. Military capabilities are strongly correlated with population size - populous countries like the US and China are powerful countries. When controlling for population size, the capabilities index shifts interpretation to the effect of per-capita capabilities, which is highly correlated with GDP per capita.

Direct contiguity: Contiguity takes the value 1 if two states either share a land boundary or are separated by less than 240 kilometers of water.

Distance: Distance is the great-circle distance between the two states' capitals (or major ports for the USA, the USSR/Russia, and Canada).

16 The indices for each country have increased somewhat over the period, but in aggregate these trends were counteracted by the entry of new and less democratic political systems following decolonialization.

17 Consequently, in 1930 none of the political systems that Polity give the maximum score of 10 is given a V-Dem Polyarchy score above 0.84 . In 2012, countries that Polity regards as maximally democratic obtain a score of 0.89 on average. There is still considerable variation among what Polity codes as close to maximally democratic. France, the US and the UK score high on the Polyarchy index, whereas Hungary and Israel have relatively low scores. 
System size: Raknerud and Hegre (1997, 390-91) show that in dyadic studies, the probability of dispute for 'low-relevance' dyads must be dependent on the number of states in the system. We enter the log of the number of independent states in the year of observation to account for this. ${ }^{18}$

Proximity of War: Raknerud and Hegre (1997) and Beck, Katz and Tucker (1998) argue that temporal dependence in BTSCS designs may be handled by adding a function of time since previous conflict in the dyad to the set of explanatory variables. We use the decay function suggested by Raknerud and Hegre (1997) here. Proximity of war is defined as $2^{(-\mathrm{py} / \alpha)}$ where $p y$ is the number of years since last conflict and $\alpha$ a half-life parameter. We set $\alpha=1$, assuming that the risk-increasing effect of a previous war is halved every year.

\section{Results}

We estimated two sets of models for all pairs of states for every year over the 1900-2010 period with the democratic peace hypothesis represented as the democracy score(s) of the stronger country, that of the weaker country, the interaction of these two, and several control variables. In the first set of models, we entered the five indicators of constraint one by one along with our control variables. Figure 3 summarizes the results from these models. Complete estimation results in table form with all control variables are found in Appendix Table A-1.

The first model (called 'Electoral accountability') enters the three terms based on the electoral accountability index along with control variables. The estimates from this model are printed in green color at the top of the figure. The points represent the estimates and the whiskers their estimated 95\% confidence interval. The two main terms are both positive, although that for the weaker country is not statistically significant. The interaction between the index values for the two countries in the dyad, on the other hand, is negative and highly significant - when both countries score highly in terms of electoral accountability, the risk of fatal dispute is much lower than if either have low scores. In line with expectations, we show in Appendix Table A-3 that the effect of electoral democracy is driven by the "Schumpeterian" core dimensions tapping into contestation - whereas suffrage does not play an independent role in promoting peace.

The second model enters the 'Legislative constraints' index terms. Again, the interaction term is negative and significant, whereas the main terms are positive and significant. Similar patterns are observed for the other three individual indicators.

18 See Raknerud and Hegre (1997) for a detailed justification of this specification. 
Figure 3. Coefficient estimates, models with the indices of constraint entered individually

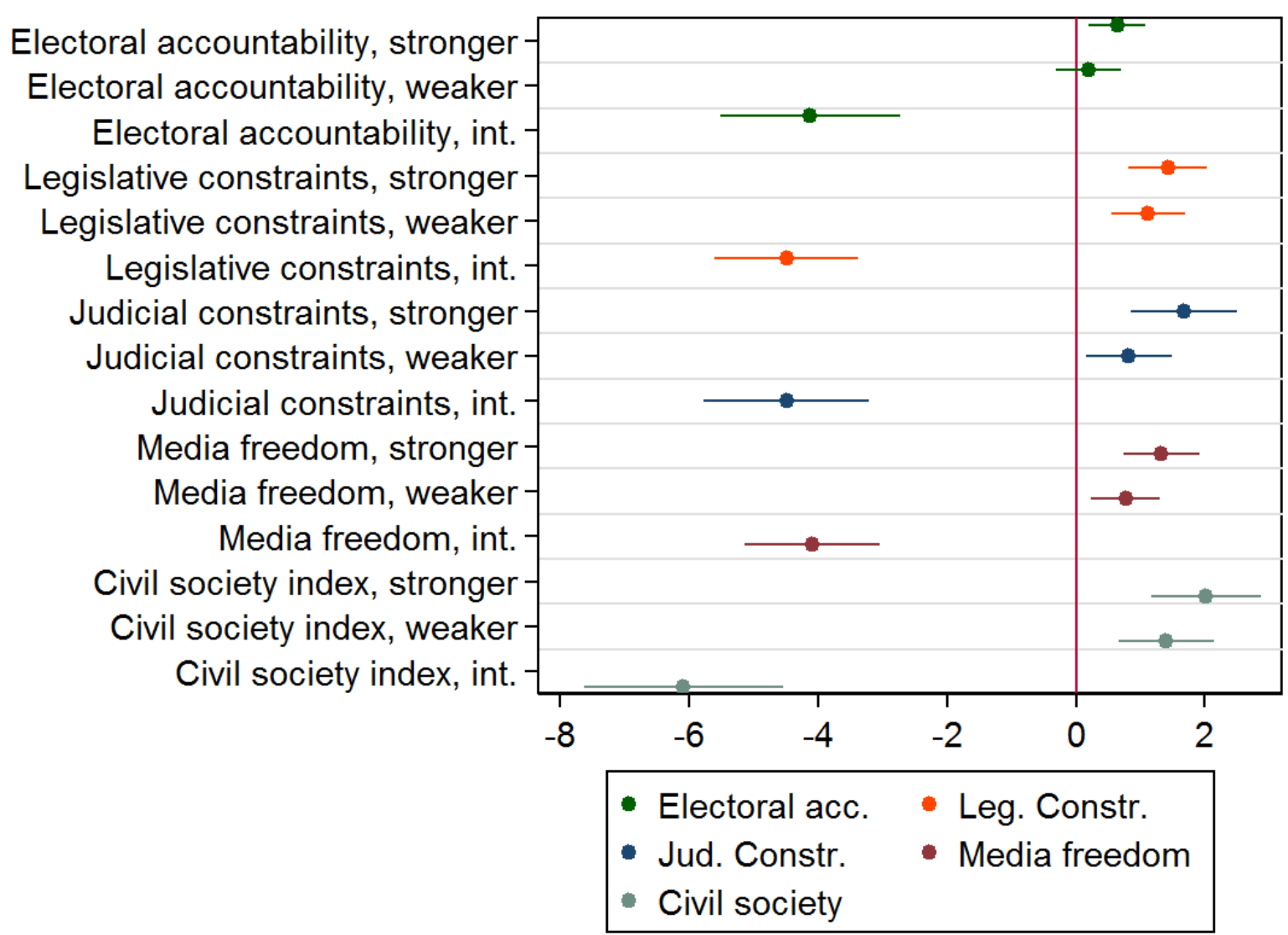

Figure created using the Stata coefplot package (Jann, 2014). Complete estimates for these models are reported in Appendix Table A-1 (columns 1-5).

Figure 4 shows that the net effect for each of these indicators is consistent with the democratic peace. In the left panels, the dashed line plots the estimated log odds of a MID when the weaker country $j$ is at the mean of the index, as a function of the score for the stronger country (along the $x$-axis). The metric for the $y$-axis is log odds relative to the case where both countries have scores of 0 for the index. The dotted and solid lines show the same when the index is one standard deviation below or above the mean. ${ }^{19}$

\footnotetext{
19 The mean here is the average value for the index across all countries for all years 1900-2010. All other variables are assumed to have values zero.
} 
Figure 4. Risk of fatal MID as a function of the individual indicators of constraint
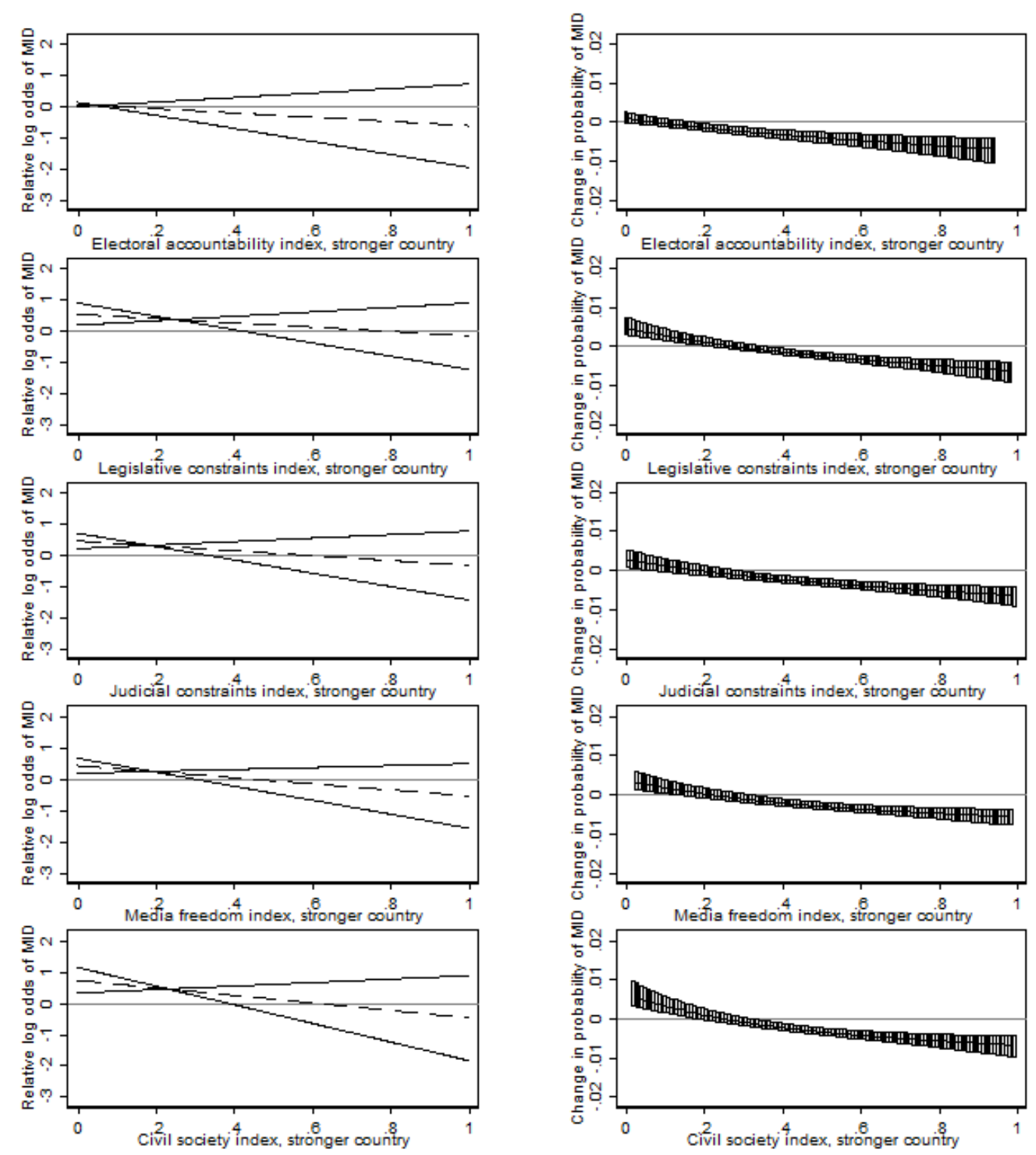

The figures to the left show estimated log odds of fatal MIDs as a function of the indicator value of the stronger country, varying the value for the weaker country. The dashed lines show this relationship when the relevant index for the weaker country is at the mean; the dotted lines when the index for the weaker country is one standard deviation below the mean, the solid lines when the index for the weaker country is one standard deviation above the mean. The figures to the right shows the marginal effect of a two standard-deviation increase in the indicator score of the weaker country as a function of the indicator value for the stronger county. Figures to the right were created using the intgph package (Zelner 2009, Tomz et al. 2003), and based on the reduced sample described in the main text.

The graph on the right plots the marginal effect of this relationship - it shows the change in the estimated probability of a fatal dispute when comparing a pair of countries where the weaker country has a value for the index one standard deviation below the mean and one standard 
deviation above, respectively, as a function of the index for the stronger country. Both these graphs show a clear dyadic democratic peace in terms of all our indices of constraint - a more democratic weaker country means a clearly lower risk of fatal MID if the stronger country is relatively democratic. ${ }^{20}$

All of our individual indicators of constraint reflect the democratic peace when entered on their own. Given the high correlation between them, however, each of them may serve as a proxy for one of the other. We investigate which of them are relatively most important along two routes.

The first is to estimate models with all the individual terms entered simultaneously. In Figure 5 , we show the results of a model that contains all terms. ${ }^{21}$ The electoral accountability index terms are not distinguishable from 0 in this model, and the media freedom index also loses most of its explanatory power in the joint model. The legislative and judicial constraint variables, on the other hand, retain separate contributions to the democratic peace. Both interaction terms are negative and the legislative constraint at least borderline significant. ${ }^{22}$ The variable that retains the most of its impact on the probability of a fatal dispute is the civil society participation index. The democratic peace seems to rest in particular on horizontal constraints on the executive and the presence (and acceptance) of strong and active civil society organizations.

The second route is to compare the models in terms of their overall fit to the data. A set of different metrics is reported in Table 2 for the six models reported in Figures 3 and 5 as well as some additional models we present below. The Akaike Information Criterion (AIC) values for each model discussed so far are reported in the 'AICfull' column. The 'Civil Society' model has the lowest AIC values, indicating as above that this variable provides the best fit within the estimation sample. The table also reports how well the different models do in terms of out-of-sample predictive performance. ${ }^{23}$ To obtain these estimates, we first reduced the size of our dataset by removing at random $95 \%$ of all the non-MID dyad years. ${ }^{24}$ We then drew half of all dyads at random, estimated the models on this sample, obtained predictions for the non-estimation sample and compared with the actual record of fatal MIDs for the non-estimation sample. We repeated this for 20 independently sampled divisions of the sample.

\footnotetext{
20 That we have plotted the democracy score of the stronger country along the $x$ axis rather than that of the weaker country is inconsequential - plots where the stronger and weaker country switch place look very similar.

21 Complete estimation results in table form with all control variables are found in Appendix Table A-1, column 6.

22 We also show in table A-3 that the combined juducial and legislative constraints index also has a negative and a statistically significant effect when eneter alongside all other constrain variables.

23 See Ward, Greenhill and Bakke (2010) for an argument for why this is a necessary complement to standard significance testing.

${ }_{24}$ The results from this asymmetrically reduced model are shown in Appendix Table A-2. Only the intercept terms change substantially compared to Table A-1.
} 
The 'AICoos' column in Table 2 show the average AICs for the 20 reduced-sample estimations. The 'AUROC' and 'Brier' columns show the Area Under the Receiver Operator Curve and the Brier scores averaged over the 20 samples. Models that predict well will have high scores on the AUROC and low Brier scores. In what follows, we place more emphasis on the Brier scores since the AUROC is tends to favor models that predict non-conflict well rather than models that also predict conflict.

Figure 5. Coefficient estimates, models with the indices of constraint entered jointly

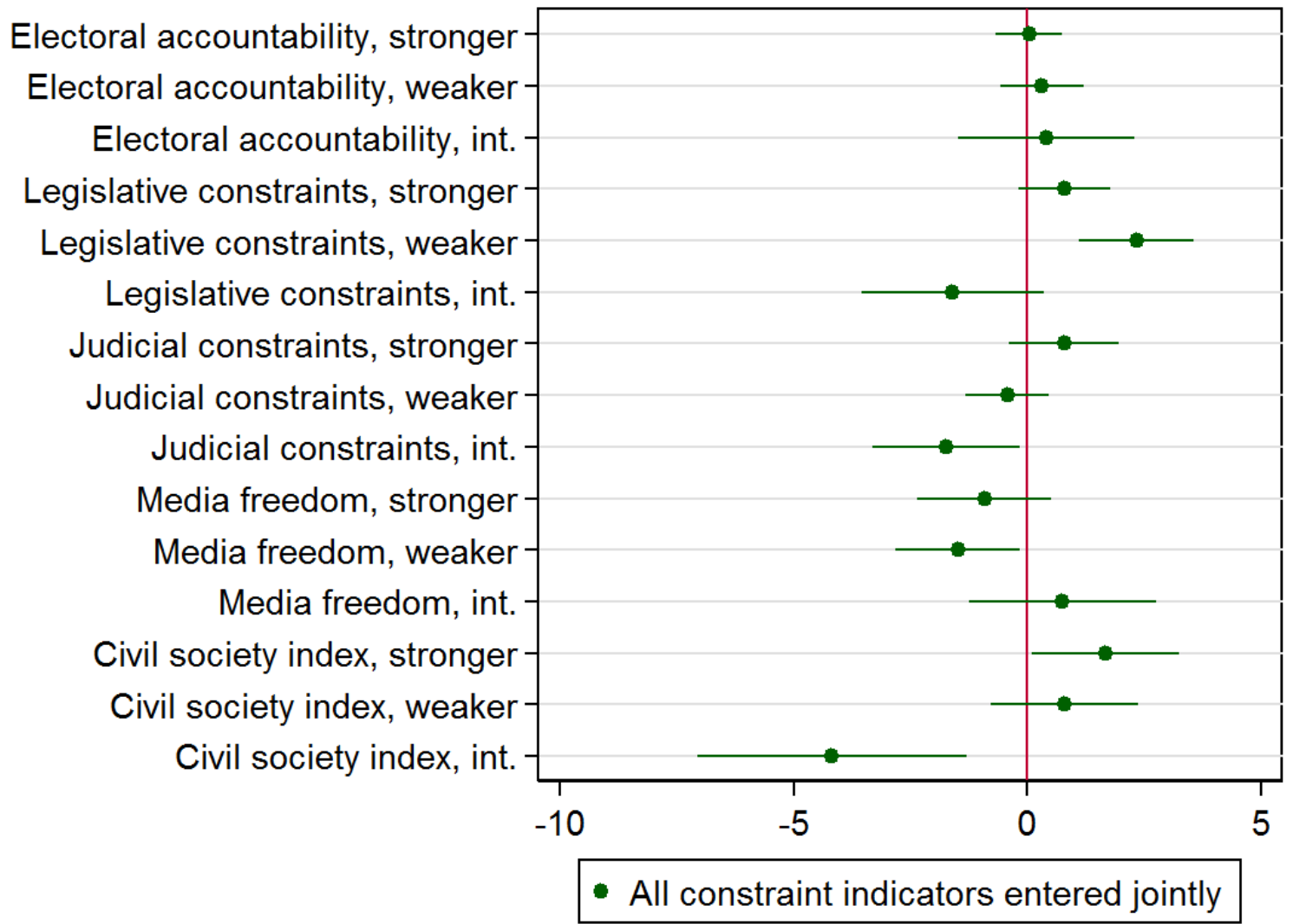

Figure created using the Stata coefplot package (Jann, 2014). Complete estimates for this model are reported in Appendix Table A-1 (model 6).

The out-of-sample evaluation of predictive performance further strengthens the impression that constraint through the electoral accountability mechanism is weaker than the other four. The AUROC is lower and the Brier higher for this model than for the other models. The out-of-sample evaluation indicates that the 'judicial constraints' and 'civil society' perform the best. The 'media freedom' model has a high area under the ROC curve, but a relatively poor Brier score. The model including all the five indicators performs considerably better than the five 
models in Figure 3 across all metrics, suggesting that the conclusions drawn from Figure 5 are still valid.

Table 2. Model summary statistics

\begin{tabular}{lllllll} 
& Model & AICfull & AICoos & AUROC & Brier & N \\
\hline $\begin{array}{l}\text { Electoral } \\
\text { accountability }\end{array}$ & 1 & 5945.7 & 766.9 & 0.9356 & 0.06588 & 541560 \\
$\begin{array}{l}\text { Legislative } \\
\text { constraint }\end{array}$ & 2 & 5917.9 & 742.4 & 0.9378 & 0.06451 & 541560 \\
Judicial constraint & 3 & 5882.2 & 742.2 & 0.9388 & 0.06371 & 541560 \\
Media freedom & 4 & 5876.4 & 753.8 & 0.9412 & 0.06384 & 541560 \\
Civil society index & 5 & 5854.5 & 756.2 & 0.9379 & 0.06290 & 541560 \\
\hline All entered jointly & 6 & 5808.3 & 737.3 & 0.9416 & 0.06175 & 541560 \\
\hline $\begin{array}{l}\text { Polity } \\
\text { Polyarchy }\end{array}$ & 7 & 5894.6 & 736.5 & 0.9402 & 0.06434 & 541560 \\
$\begin{array}{l}\text { Liberal democracy } \\
\text { Participatory }\end{array}$ & 9 & 5885.3 & 733.5 & 0.9395 & 0.06378 & 541560 \\
democracy & 10 & 5882.3 & 742.2 & 0.9407 & 0.06232 & 541560 \\
$\begin{array}{l}\text { Deliberative } \\
\text { democracy }\end{array}$ & 11 & 5886.2 & 758.6 & 0.9362 & 0.06325 & 541560 \\
$\begin{array}{l}\text { Egalitarian } \\
\text { democracy }\end{array}$ & 12 & 5899.1 & 746.5 & 0.9369 & 0.06392 & 541560 \\
\hline $\begin{array}{l}\text { Schumpeter } \\
\begin{array}{l}\text { Horizontal } \\
\text { constraint }\end{array}\end{array}$ & 13 & 5916.4 & 744.8 & 0.9372 & 0.06521 & 541560 \\
Lean civil society & 14 & 5873.3 & 713.0 & 0.9401 & 0.06297 & 541560 \\
\hline
\end{tabular}

Figure 6 illustrates the implications of the electoral accountability model (model 1) compared to the joint constraint model (model 6) for selected dyads in 2010. For each pair of countries, we calculated how much the "democraticness" of their institutions alter the risk (measured as log odds) of conflict relative to what is explained by the control variables. We plot the effect of the electoral accountability model along the horizontal axis and that of the joint constraint model along the vertical one. Democratic pairs such as Great Britain and India (IND-GBR) have a low risk of conflict according to both models and are located in the lower left corner. ${ }^{25}$ Pairs with one democracy and one non-democracy such as Great Britain and North Korea (GBR-PRK)

25 This result is in line with the studies on "political similarity" (Peceny, Beer \& Sanchez-Terry 2002; Raknerud \& Hegre 1997). 
have a high risk and are found in the upper right one. The diagonal line represents the case where the two models yield similar predicted effects.

Figure 6. Predicted effect of institutional setup for risk of conflict, electoral accountability (model 1) and joint constraint (model 6), selected dyads, 2010

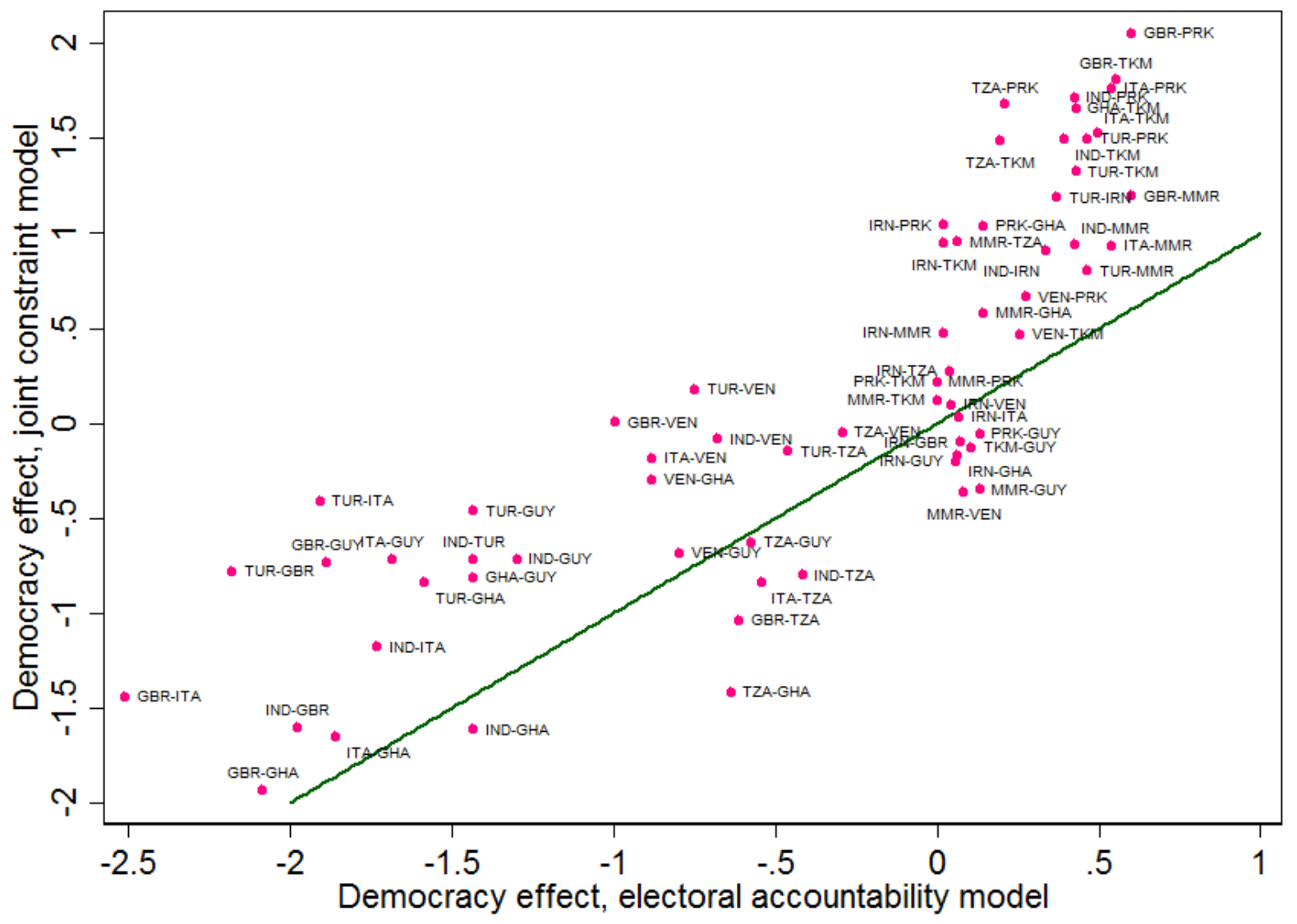

The figure shows how much the indices of constraint change log odds of conflict for each dyad relative to what is predicted by the control variables in the model. The values along the $\mathrm{x}$ axis are the sums $\beta_{1} x_{i}+\beta_{2} x_{j}+\beta_{3} x_{i j}$ where $x_{i}$ is the electoral accountability index value for country $i, x_{j}$ the value for country $j, x_{i j}$ the interaction term, and the $\beta$ terms the corresponding from the electoral accountability model. The values along the y axis are constructed in a similar way for all the index of constraint terms in the joint constraint model.

The figure shows that models that reflect multiple dimensions of accountability give a more nuanced picture of interstate conflict risk. The electoral accountability model indicates that autocracies such as North Korea, Turkmenistan, and Myanmar have equally high risk of conflict with democracies. The joint constraint model distinguish much better between them - the 
predicted risk of conflict between GBR and North Korea is twice as high as between GBR and Myanmar. ${ }^{26}$

Our results suggest that the democratic peace rests less on formal vertical mechanisms of electoral accountability than on horizontal and informal vertical constraint. Illiberal democracies, hybrid regimes, and electoral authoritarian regimes such as Turkey and Venezuela in 2010 continue to hold competitive elections but harass civil society organizations and undermine horizontal constraints on their ambitious executives. The joint constraint model indicates that the pairs of countries they form are more bellicose than the electoral accountability model suggests. The difference in the predictions from the two models is less marked for Venezuela than for Turkey, however, since V-Dem regards Venezuela to have a much stronger civil society in 2010 .

Similarly, a number of weaker at risk democracies, such as Kenya or Tanzania, despite their low level of vertical electoral accountability should have a lower risk of conflict with other democracies than these two illiberal examples. Pairs of countries including Ghana or Tanzania, for instance, score relatively better on civil society participation than on electoral accountability. Figure 6 shows that these pairs have very low predicted risk of conflict by the joint constraint model, but are placed close to the middle by the electoral model.

By implication, the vast expansion of electoral accountability during the $20^{\text {th }}$ century demonstrated in Figure 3 may have considerably less positive implications for international peace than the steady improvement in all five indices of constraint seen from 1990 and onwards.

For comparison with more conventional democratic peace investigations, we also estimated a set of models using the five standardized V-Dem indices of democracy as well as with the Polity index of democracy. The detailed results are found in Appendix Table A-4, and the model summary statistics are reported in Table 2 . The democratic peace is supported no matter which index we are using - the interaction term is negative and significant in each of them. The model summary statistics in Table 2 suggest they perform less well than our theoretically derived institutions of constraint, however.

Confirming the impression that horizontal accountability is more important than the vertical, the V-Dem Polyarchy index (that focus in particular on the vertical aspect of democracy) performs worse than the V-Dem Liberal Democracy index (LDI), that captures the more horizontal forms of constraint that more liberal democracies enjoy. The model using the LDI

26 The predicted change in log odds due to the electoral accountability model (the sum ${ }_{1} x_{i}+{ }_{2} x_{j}+{ }_{3} x_{i j}$ ) is 2.05 for GBR-PRK and 1.19 for GBR-MMR. The predicted odds ratio is 2.36 , the exponential of the difference between these two. Since these are rare events, the ratio of predicted probabilities are very close to this figure. 
has AIC, AUROC, and Brier values that are better than the five single-indicator models. The three other V-Dem indices fit the data (within and out of sample) roughly as well as the Polyarchy index. The Polity index has the poorest performance in terms of AIC and Brier. None of the models based on these standard one-dimensional indices perform nearly as well as the model with all five indices of constraint entered jointly. Figure A-2 shows that the predictions from the Polity model resemble those from our electoral accountability model.

Table 2 also report the results from three models with alternative operationalizations of our indices of constraint. In the "Schumpeter" model, we use the minimalist measure described above, controlling for the extent of suffrage. This operationalization of the 'formal vertical' democratic peace fits the data better than the more extensive one, but still not as well as the horizontal and informal vertical ones (models 3, 4, 6, and 7). We also merged the legislative and judiciary indices of constraint into one joint 'horizontal constraint' index. As was clear from Figure 5, the two indices of formal horizontal constraint pull in the same direction, so the joint indicator makes for a more parsimonious and effective model. Finally, we estimate a model with a much leaner version of the civil-society participation index, omitting information on civil society input on nominations, civil society consultation, and women's participation in civil society organizations. The model using the lean civil society measure performs less well than our preferred corresponding metric, but still better than the electoral accountability model.

\section{Conclusion}

In this article we have introduced two novelties into the study of the democratic peace. First, we make use of the V-Dem data and demonstrate that it improves on Polity, the dominant measure in that literature, along at least two dimensions. First, V-Dem has a superior concept-tomeasurement consistency, given its starting point was the overt modeling of democracy. Moreover, the V-Dem data are vastly more detailed than Polity, allowing us to operationalize much more precise theoretical mechanisms than the simpler datasets. Accordingly, our fit tests show that our V-Dem-based indices model the democratic peace much better than Polity, both in terms of in-sample goodness of fit and out-of-sample predictive performance.

Second, and more importantly, we have identified a subset of the multiplicity of democracy's attributes that seem to explain its ability to deter war-like behavior. Specifically we show that, when entered individually, electoral accountability, judicial and legislative constraints on the executive, media freedom and civil society participation promote the democratic peace, when controlling for the other standard determinants of inter-state disputes. When pitted against each 
other, however, only horizontal constraints on the executive and civil society participation continue to have a direct effect on dyadic peace. We thus find most consistent support for the horizontal and informal-vertical accountability mechanisms underlying the democratic peace. Earlier we cited the claim of Maoz and Russett $(1993,626)$ that 'the mobilization of ... general public opinion' matters at the same order of importance as the 'variety of institutions that make up the system of government'. Our findings provide support for the institutional side of their claims but to some extent contradict what they say about social mobilization. We confirm important aspects of earlier work on the democratic peace such as Doyle's (1983a,b) 'liberal peace' argument and Choi's (2010) focus on legislative veto players. However, our results on the role of civil society suggest that social mobilization is also important. The exclusion of the peace-making role of civil society in this literature may well be a function of the past paucity of data to measure it. Given the strong model fit and predictive performance of the models that include this new V-Dem variable, this omission has been an important oversight in the literature from the perspective of our constraint-based theorization of the mechanisms behind the democratic peace.

At first sight, the policy implication of these findings would seem clear: in order to promote international security, what needs strengthening is not electoral competitiveness or the quality of elections but horizontal mechanisms of effective constraints on the executive, a more vibrant civil society that monitors and constrains those exercising executive power, or a combination of the two. If the goal is order in the international system, legislative and judicial reforms should trump electoral reform, and the promotion of the initiatives of an organized and active citizenry in civil society seems more important than the strengthening of opposition political parties. However, in as much as the mechanism of electoral accountability is connected to these other aspects of democracy, it cannot be easily dismissed from a policy agenda to promote peace. Most importantly, it cannot be ruled out that the promotion of electoral accountability is also a way of strengthening the other accountability mechanisms. Students of judicial independence and oversight, for example, tend to stress the logic of the "insurance argument", which holds that competitiveness at the polls undergirds executive support for judicial constraints by creating uncertainty about the future prospects of staying in office (for an overview, see Vanberg 2015). Similarly, to the extent that the state can constrain and harass civil society, the strength of civil society is arguably not simply an independent source of its own but is guaranteed by the sort of robust competition at the polls that protects the freedoms of association and expression that civil society requires. 
Despite our reticence to completely reject the impact of electoral accountability, we still believe we have moved the democratic peace literature forward by stressing the stronger relative importance of the non-electoral mechanisms of accountability. The essence of constraint is preventing those who exercise executive power from acting in an arbitrary and ill-advised fashion, leading to destructive forms of interstate conflict. The electoral mechanism does determine who holds executive office, but its constraining power is time dependent, tied to the elections cycle. Both the vertical constraining power of civil society and horizontal constraints posed the countervailing powers of the legislative and judicial branches of government are not dependent on the timing of elections, but consistent over time. This plausibly helps to explain why they are a more effective constraint on the kinds of arbitrary executive action that pose a threat to peace than the constraints posed by threat of losing office in the future. 


\section{References}

Babst, Dean V. 1964. Elective Governments - A Force for Peace. The Wisconsin Sociologist $3(1): 9-14$.

Barber, Benjamin. 1984. Strong Democracy: Participatory Politics for a New Age. Berkeley, CA: University of California Press.

Beck, Nathaniel, Jonathan N. Katz, and Richard Tucker. 1998. Taking Time Seriously: Time-Series-Cross-Section Analysis with a Binary Dependent Variable. American Journal of Political Science 42(4):1260-1288.

Bennett, Scott D. 2006. Toward a Continuous Specification of the Democracy-Autocracy Connection. International Studies Quarterly 50(2):313-338.

Boix, Carles, Michael Miller, and Sebastian Rosato. 2013. A Complete Dataset of Political Regimes, 1800-2007. Comparative Political Studies 46(12):1523-1524.

Bremer, Stuart A. 1992. Dangerous Dyads: Conditions Affecting the Likelihood of Interstate War, 1816-1965. Journal of Conflict Resolution 36(2):309-341.

Bueno de Mesquita, Bruce, James D. Morrow, Randolph M. Siverson, and Alastair Smith. 1999. An Institutional Explanation of the Democratic Peace. American Political Science Review 93(4):791-807.

Bueno de Mesquita, Bruce, Randolph M. Siverson, and Gary Woller. 1992. War and the Fate of Regimes: A Comparative Analysis. American Political Science Review 86(3):638-646.

Bush, George W. 2003. President Bush Discusses Iraq in Veterans Day Address. Available at (http://georgewbush-whitehouse.archives.gov/news/releases/2003/11/20031111-10.html). Accessed February 18, 2016.

Chalmers, Douglas A., Scott B. Martin, and Kerianne Pister. 1997. Associative Networks: New Structures of Representation for the Popular Sectors? In The New politics of Inequality in Latin America: Rethinking Participation and Representation, edited by Douglas A. Charlmers, Carlos M. Vilas, Katherine Hite, Scott B. Martin, Kerianne Piester, and Monique Segarra, 543-582. Oxford: Oxford University Press.

Choi, Seung-Whan. 2010. Legislative Constraints: A Path to Peace? Journal of Conflict Resolution 54(3):438-470. 
Choi, Seung-Whan. 2013. The Democratic Peace through an Interaction of Domestic Institutions and Norms: Executive Constraints and Rule of Law. Armed Forces and Society 39(2):255-283.

Clinton, Bill. 1994. State of the Union Address, January 25, 1994. Available at (http://www.washingtonpost.com/wp-srv/politics/special/states/docs/sou94.htm). Accessed February 17, 2016.

Coppedge, Michael, John Gerring, David Altman, Michael Bernhard, Steven Fish, Allen Hicken, Matthew Kroenig, Staffan I. Lindberg, Kelly McMann, Pamela Paxton, Holli A. Semetko, Svend-Erik Skaaning, Jeffrey Staton, and Jan Teorell. 2011. Conceptualizing and Measuring Democracy: A New Approach. Perspectives on Politics 9(2):247-267.

Coppedge, Michael, John Gerring, Staffan Lindberg, Svend-Erik Skaaning, Jan Teorell, David Altman, Michael Bernhard, Steven Fish, Adam Glynn, Allen Hicken, Carl Henrik Knutsen, Pamela Paxton, Daneil Pemstein, Jeffrey Staton, Brigitte Zimmerman, Rachel Sigman, Frida Andersson, Valeriya Mechkova, and Farhad Miri. 2016a. Varieties of Democracy (V-Dem). Codebook v6. Göteborg: V-Dem Institute. Available at (https://www.v-dem.net/media/filer_public/d1/24/d124efd5-7ff5-4175a1ed-f294984084d0/v-dem_codebook_v6.pdf). Accessed June 15, 2017.

Coppedge, Michael, John Gerring, Staffan I. Lindberg, Svend-Erik Skaaning, Jan Teorell, David Altman, Michael Bernhard, M. Steven Fish, Adam Glynn, Allen Hicken, Carl Henrik Knutsen, Kyle Marquardt, Kelly McMann, Farhad Miri, Pamela Paxton, Daniel Pemstein, Jeffrey Staton, Eitan Tzelgov, Yi-ting Wang, and Brigitte Zimmerman. 2016b. V-Dem Country-Year Dataset v6. Varieties of Democracy (V-Dem) Project. Available at (https://www.v-dem.net/en/data/data-version-6/). Accessed June 15, 2017.

Coppedge, Michael, John Gerring, Staffan I. Lindberg, Svend-Erik Skaaning, Jan Teorell, Frida Andersson, Kyle Marquardt, Valeriya Mechkova, Farhad Miri, Daniel Pemstein, Josefine Pernes, Natalia Stepanova, Eitan Tzelgov, and Yi-ting Wang. 2016c. V-Dem Methodology v6. Varieties of Democracy (V-Dem) Project. Available at (https://www.v-dem.net/files/42/Methodology\%20v6.pdf). Accessed June 15, 2017.

Dahl, Robert A. 1971. Polyarchy: Political Participation and Opposition. New Haven, CT: Yale University Press.

Dalton, Russell J., Susan E. Scarrow, and Bruce E. Cain. 2003. New Forms of Democracy? Reform and Transformation of Democratic Institutions. In Democracy Transformed? Expanding 
Political Opportunities in Advanced Industrial Democracies, edited by Bruce E. Cain, Russell J. Dalton, and Susan E. Scarrow, 1-22. Oxford: Oxford University Press.

Dixon, William J. 1994. Democracy and the Peaceful Settlement of International Conflict. American Political Science Review 88(1):1-17.

Downes, Alexander B., and Todd S. Sechser. 2012. The Illusion of Democratic Credibility. International Organization 66(3):457-489.

Doyle, Michael W. 1983a. Kant, Liberal Legacies, and Foreign Affairs. Philosophy \& Public Affairs 12(3):205-235.

Doyle, Michael W. 1983b. Kant, Liberal Legacies, and Foreign Affairs, Part II. Philosophy \& Public Affairs 12(4):323-353.

Doyle, Michael W. 1986. Liberalism and World Politics. American Political Science Review 80(4):1151-1169.

Dryzek, John. 2002. Deliberative Democracy and Beyond. Oxford: Oxford University Press.

Eckstein, Harry, and Ted Robert Gurr. 1975. Patterns of Authority: A Structural Basis of Political Inquiry. New York: Wiley.

Ekiert, Grzegorz, and Jan Kubik. 1999. Rebellious Civil Society, Popular Protest and Democratic Consolidation in Poland. Ann Arbor, MI: University of Michigan Press.

Ember, Carol R., Melvin Ember, and Bruce M. Russett. 1992. Peace between Participatory Polities: A Cross-Cultural Test of the "Democracies Rarely Fight Each Other" Hypothesis. World Politics 44(4):573-599.

Fearon, James D. 1994. Domestic Political Audiences and the Escalation of International Disputes. American Political Science Review 88(3):577-592.

Fearon, James D. 1995. Rationalist Explanations for War. International Organization 49(3):379-379.

Franceschet, Antonio. 2000. Popular Sovereignty or Cosmopolitan Democracy? Liberalism, Kant and International Reform. European Journal of International Relations 6(2):277-302.

Fung, Arshon, and Erik Olin Wright. 2003. Countervailing Power in Empowered Participatory Governance. In Deepening Democracy: Institutional Innovation in Empowered Participatory Governance, edited by Arshon Fung and Erik Olin Wright, 259-290. London: Verso.

Gartzke, Erik. 2007. The Capitalist Peace. American Journal of Political Science 51(1):166-191.

Gartzke, Erik A. 1998. Kant We All Just Get Along? Opportunity, Willingness, and the Origins of the Democratic Peace. American Journal of Political Science 42(1):1-27. 
Gates, Scott, Torbjørn L. Knutsen, and Jonathan W. Moses. 1996. Democracy and Peace: A More Skeptical View. Journal of Peace Research 33(1):1-10.

Gibler, Douglas. 2010. The Territorial Peace: Borders, State Development, and Intrnational Conflict. Cambridge: Cambridge University Press.

Gleditsch, Kristian Skrede, and Michael D. Ward. 1997. Double Take: A Re-Examination of Democracy and Autocracy in Modern Polities. Journal of Conflict Resolution 41(3):361-383.

Gould, Carol. 1988. Rethinking Democracy: Freedom and Social Cooperation in Politics, Economy and Society. Cambridge, UK: Cambridge University Press.

Gurr, Ted Robert. 1974. Persistence and Change in Political Systems, 1800-1971. American Political Science Review 68(4):1482-1504.

Hegre, Håvard. 2008. Gravitating toward War. Preponderance May Pacify, but Power Kills. Journal of Conflict Resolution 52(4):566-589.

Hegre, Håvard. 2009. Trade Dependence or Size Dependence?: The Gravity Model of Trade and the Liberal Peace. Conflict Management and Peace Science 26(1):26-45.

Hegre, Håvard. 2014. Democracy and Armed Conflict. Journal of Peace Research 51(2):159-172.

Hegre, Håvard, John R. Oneal, and Bruce Russett. 2010. Trade Does Promote Peace: New Simultaneous Estimates of the Reciprocal Effects of Trade and Conflict. Journal of Peace Research 47(6):763-774.

Hermet, Guy, Richard Rose, and Alain Rouquie. 1978. Elections without Choice. London, Palgrave Macmillan.

Houtzager, Peter P., and Adrian Gurza Lavalle. 2010. Civil Society's Claims to Political Representation in Brazil. Studies in Comparative International Development 45(1):1-29.

Hutchings, Vincent L. 2005. Public Opinion and Democratic Accountability: How Citizens Learn about Politics. Princeton, NJ: Princeton University Press.

Jaggers, Keith, and Ted R. Gurr. 1995. Transitions to Democracy: Tracking Democracy's Third Wave with the Polity III Data. Journal of Peace Research 32(4):469- 482.

Jahn, Beate. 2005. Kant, Mill, and Illiberal Legacies in International Affairs. International Organization 59(1):177-207.

Jann, Ben. 2014. Plotting Regression Coeffcients and Other Estimates. Stata Journal 17:708-737.

Kant, Immanuel. [1795] 1991. Perpetual Peace: A Philosophical Sketch. In Kant: Political Writings, edited by Hans Reiss, 93-130. Cambridge: Cambridge University Press. 
Lindberg, Staffan I. 2013. Mapping Accountability: Core Concept and Subtypes. International Review of Administrative Sciences 79(2):202-226.

Lindberg, Staffan I., Michael Coppedge, John Gerring, Jan Teorell, Daniel Pemstein, Eitan Tzelgov, Yi-ting Wang, Adam Glynn, David Altman, Michael Bernhard, Steven Fish, Alan Hicken, Matthew Kroenig, Kelly McMann, Pamela Paxton, Megan Reif, Svend-Erik Skaaning, and Jeffrey Staton. 2014. V-Dem: A New Way to Measure Democracy. Journal of Democracy 25(3):159-169.

Macpherson, C.B. 1977. The Life and Times of Liberal Democracy. Oxford: Oxford University Press.

Maoz, Zeev. 2005. Dyadic MID Dataset (version 2.0). Available at (http://vanity.dss.ucdavis.edu/ maoz/dyadmid.html). Accessed June 15, 2017.

Maoz, Zeev, and Bruce M. Russett. 1993. Normative and Structural Causes of Democratic Peace, 1946-1986. American Political Science Review 87(3):624-638.

Marshall, Monty G. 2014. Polity IV Project: Political Regime Characteristics and Transitions, 1800-2009. Available at (http://www.systemicpeace.org/polity/polity4.htm). Accessed January 16, 2014.

Merkel, Wolfgang. 2004. Embedded and Defective Democracies. Democratization 11(5):33-58.

Mousseau, Michael. 2000. Market Prosperity, Democratic Consolidation, and Democratic Peace. Journal of Conflict Resolution 44(4):472-507.

Mousseau, Michael. 2009. The Social Market Roots of Democratic Peace. International Security 33(4):52-86.

Mousseau, Michael. 2013. The Democratic Peace Unraveled: It's the Economy. International Studies Quarterly 57(1):186-197.

Munck, Gerardo L. 2009. Measuring Democracy: A Bridge between Scholarship and Politics. Baltimore, MD: Johns Hopkins University Press.

O'Donnell, Guillermo. 1998. Horizontal Accountability in New Democracies. Journal of Democracy 9(3):112-126.

Palmer, Glenn, Vito d'Orazio, Michael Kenwick, and Matthew Lane. 2015. The MID4 dataset: Procedures, Coding Rules and Description. Conflict Management and Peace Science 32(2):222-242.

Pateman, Carole. 1970. Participation and Democratic Theory. Cambridge, UK: Cambridge University Press. 
Peceny, Mark, Caroline C. Beer, and Shannon Sanchez-Terry. 2002. Dictatorial Peace. American Political Science Review 96(1):15-26.

Pemstein, Daniel, Kyle L. Marquardt, Eitan Tzelgov, Yi-ting Wang and Farhad Miri. 2015. "The V-Dem Measurement Model: Latent Variable Analysis for Cross-National and Cross-Temporal Expert-Coded Data." V-Dem Institute Working Paper Series 2015: 21, December 2015. Available at (https://ssrn.com/abstract=2613421). Accessed June 15, 2017.

Peruzzotti, Enrique. 2007. Civil Society, Representation and Accountability: Restating Current Debates on the Representativeness and Accountability of Civic Associations. In NGO Accountability. Politics, Principles and Innovations, edited by Lisa Jordan and Peter Van Tuijl. London: Earthscan.

Prins, Brandon. 2003. Institutional Instability and the Credibility of Audience Costs: Political Participation and Interstate Crisis Bargaining, 1816-1992. Journal of Peace Research 40(1):67-84.

Przeworski, Adam, Michael E. Alvarez, Jose Antonio Cheibub, and Fernando Limongi. 2000. Democracy and Development. Political Institutions and Well-Being in the World, 1950-1990. Cambridge, UK: Cambridge University Press.

Przeworski, Adam, Susan C. Stokes, and Bernard Manin. 1999. Democracy, Accountability and Representation. Cambridge, UK: Cambridge University Press.

Raknerud, Arvid, and Håvard Hegre. 1997. The Hazard of War: Reassessing the Evidence for the Democratic Peace. Journal of Peace Research 33(4):385-404.

Reiter, Dan, and Allan C. Stam. 1998. Democracy, War Initiation, and Victory. American Political Science Review 92(2):377-389.

Rosato, Sebastian. 2003. The Flawed Logic of Democratic Peace Theory. American Political Science Review 97(4):585-602.

Rummel, Rudolph J. 1983. Libertarianism and International Violence. Journal of Conflict Resolution $27(1): 27-71$.

Saward, Michael. 1998. The Terms of Democracy. Oxford: Polity.

Schedler, Andreas. 1999. Conceptualizing Accountability. In The Self-Restraining State: Power and Accountability in New Democracies, edited by Andreas Schedler, Larry Diamond, and Marc Plattner, 13-28. Boulder, CO: Lynne Rienner.

Schmitter, Phillippe C. 1992. The Consolidation of Democracy and Representation of Social Groups. American Behavioral Scientist 35(4-5):422-49. 
Schultz, Kenneth A. 1999. Do Democratic Institutions Constrain or Inform? Contrasting Two Institutional Perspectives on Democracy and War. International Organization 53(2):233-266.

Schumpeter, Joseph. [1942] 2003. Capitalism, Socialism and Democracy. London: Routledge.

Schweller, Randall L. 1992. Domestic Structure and Preventive War: Are Democracies More Pacific? World Politics 44(2):235-269.

Semetko, Holly. (2009). Election Campaigns, Partisan Balance, and the News Media. In: Norris Pipa (eds.) Public Sentinel. New Media and the Governance Agenda. Washington, D.C.: The World Bank.163-192.

Singer, J. David, Stuart Bremer, and John Stuckey. 1972. Capability Distribution, Uncertainty, and Major Power War, 1820-1965. In Peace, War, and Numbers, edited by Bruce M. Russett, 19-48. Beverly Hills, CA: Sage.

Small, Melvin, and J. David Singer. 1976. The War-Proneness of Democratic Regimes, 1816-1965. Jerusalem Journal of International Relations 1(4):50-69.

Smulovitz, Catalina, and Enrique Peruzzotti. 2000. Societal Accountability in Latin America. Journal of Democracy 11(4):147-158.

Snyder, Jack, and Erica D. Borghard. 2011. The Cost of Empty Threats: A Penny, Not a Pound. American Political Science Review 105:437-456.

Tomz, Michael, Jason Wittenberg, and Gary King. 2003. CLARIFY: Software for Interpreting and Presenting Statistical Results." Journal of Statistical Software. Available at (http://j.mp/k3k0rx). Accessed June 15, 2017.

Trachtenberg, Marc. 2012. Audience Costs: An Historical Analysis. Security Studies 21(1):3-42.

Tsebelis, George. 1995. Decision Making in Political Systems: Veto Players in Presidentialism, Parliamentarism, Multicameralism, and Multipartyism. British Journal of Political Science 25(3):289-326.

Vanberg, Georg. 2015. Constitutional Courts in Comparative Perspective: A Theoretical Assessment. Annual Review of Political Science 18: 167-185.

Voltmer, Katrin. 2009. The Media, Government Accountability and Citizen Engagement. In Public Sentinel: New Media and the Governance Agenda, edited by Pippa Norris, 137-159. Washington, D.C.: The World Bank.

Ward, Michael D., Brian D. Greenhill, and Kristin M. Bakke. 2010. The Perils of Policy by P-value: Predicting Civil Conflicts. Journal of Peace Research 47(4):363-375. 
Weart, Spencer. 1998. Never at War: Why Democracies Will Not Fight One Another. New Haven and London: Yale University Press.

Weeks, Jessica L. 2008. Autocratic Audience Costs: Regime Type and Signaling Resolve. International Organization 62(1):35-64.

Werner, Suzanne. 2000. The Effects of Political Similarity on the Onset of Militarized Disputes, 1816-1985. Political Research Quarterly 53(2):343-374.

Zelner, Bennet A. 2009. Using Simulation to Interpret Results from Logit, Probit, and Other Nonlinear Models. Strategic Management Journal 30:1335-1348. 


\section{Appendix}

Figure A-1. Scatterplots showing correlations between the five indices of accountability as well as the V-Dem Polyarchy/Electoral democracy index, 2010.

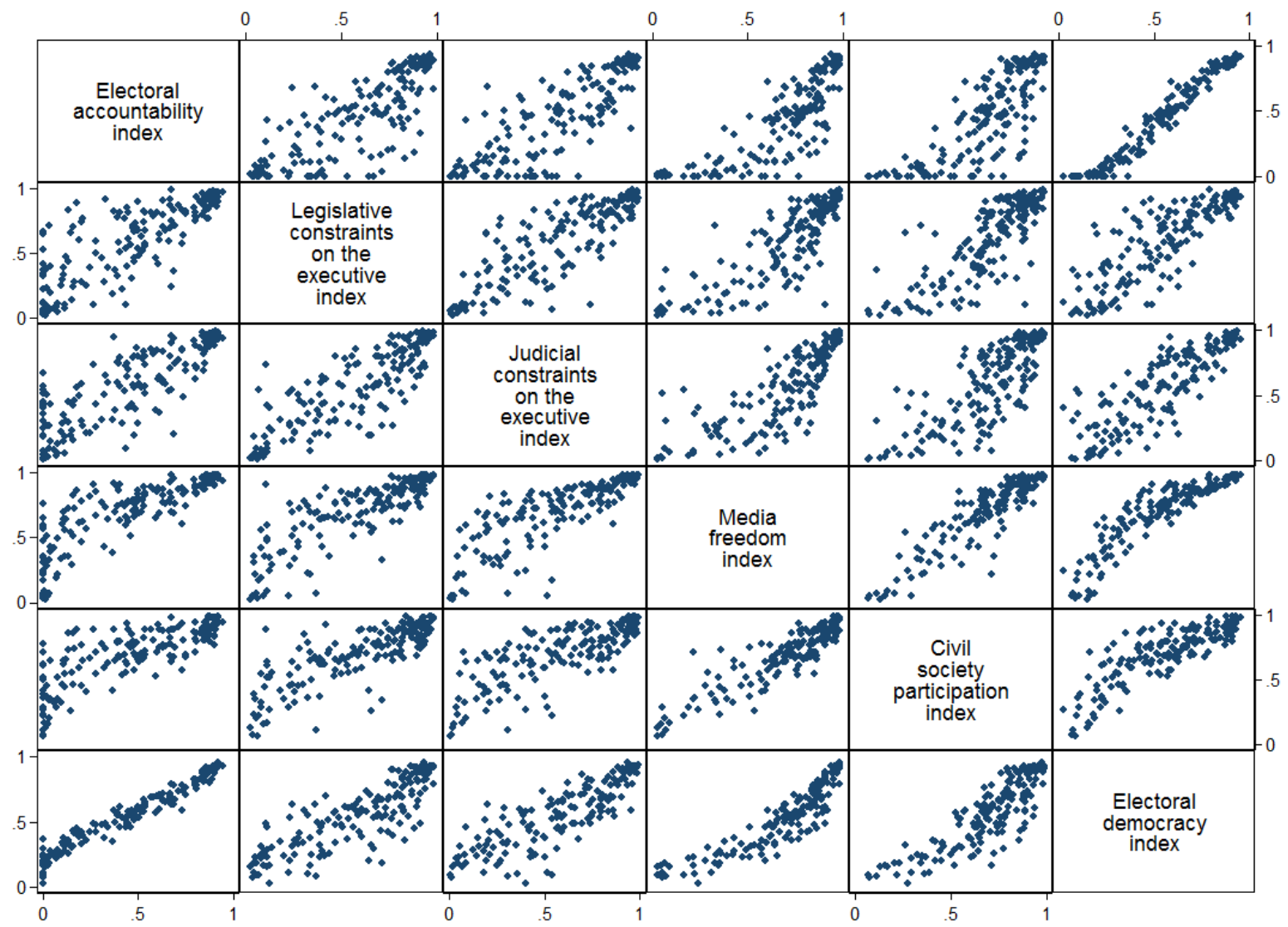


Figure A-2. Predicted effect of institutional setup for risk of conflict, Polity and joint constraint model, selected dyads, 2010

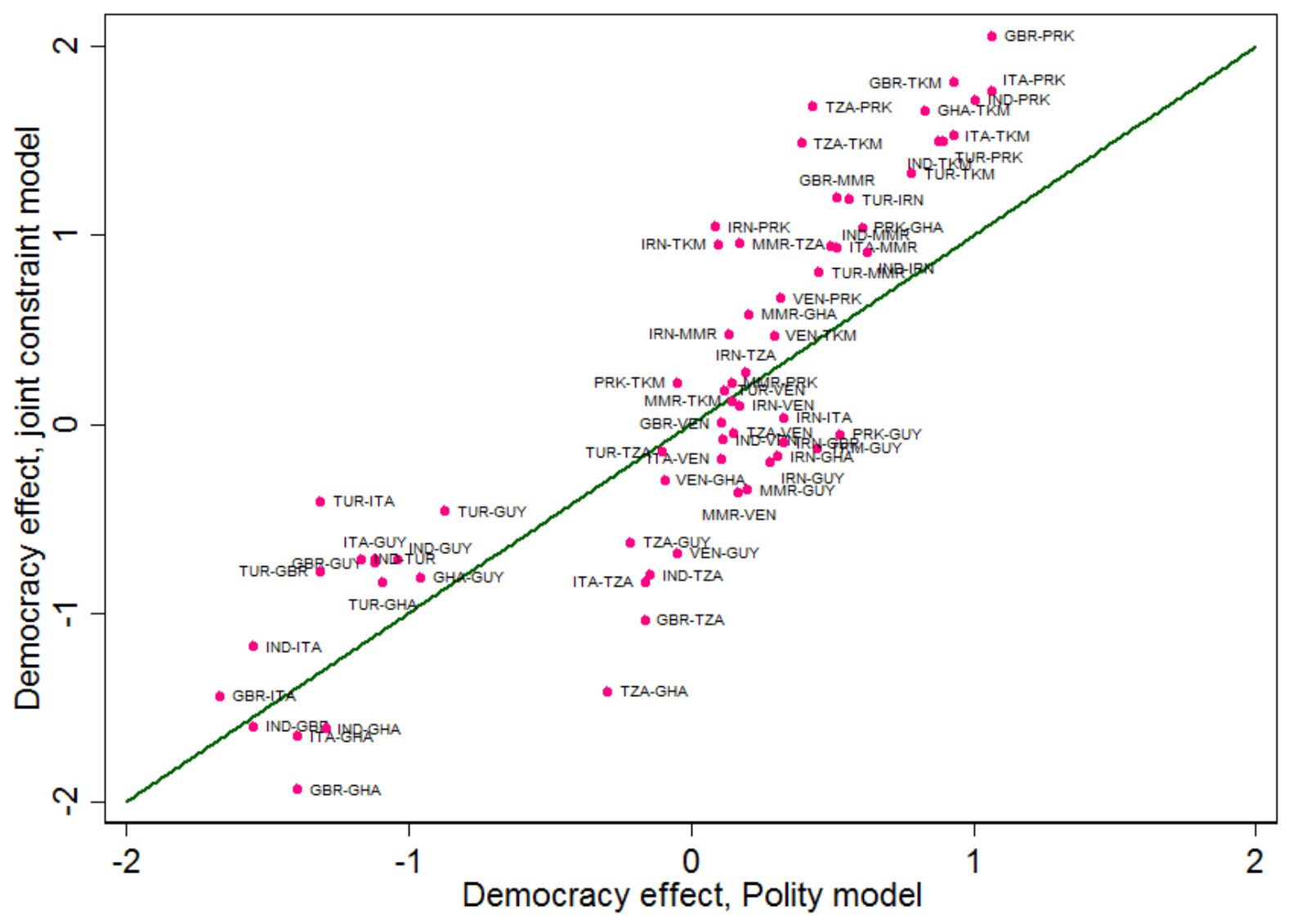

The figure shows how much the indices of constraint change log odds of conflict for each dyad relative to what is predicted by the control variables in the model. The values along the $\mathrm{x}$ axis are the sums $\beta_{l} x_{i}+\beta_{2} x_{j}+\beta_{3} x_{i j}$ where $x_{i}$ is the Polity index value for country $i, x_{j}$ the value for country $j$, $x_{i j}$ the interaction term, and the $\beta$ terms the corresponding from the Polity model. The values along the $y$ axis are constructed in a similar way for all the index of constraint terms in the joint constraint model. 
Table A-1. Estimation results, models with the five indices of constraint entered separately (columns 1-5) and jointly (column 6). Full sample.

\begin{tabular}{|c|c|c|c|c|c|c|}
\hline & $\begin{array}{l}1 \text { Electoral } \\
\text { accountability }\end{array}$ & $\begin{array}{l}2 \text { Legislative } \\
\text { constraints }\end{array}$ & $\begin{array}{l}3 \text { Judicial } \\
\text { constraints }\end{array}$ & $\begin{array}{l}4 \text { Media } \\
\text { freedom }\end{array}$ & $\begin{array}{l}5 \text { Civil society } \\
\text { index }\end{array}$ & $\begin{array}{l}6 \text { Joint } \\
\text { constraint }\end{array}$ \\
\hline \multicolumn{7}{|l|}{ mzfatal_new } \\
\hline \multirow[t]{2}{*}{ Electoral accountability, stronger } & $0.638^{* *}$ & & & & & 0.0370 \\
\hline & $(2.84)$ & & & & & $(0.10)$ \\
\hline \multirow[t]{2}{*}{ Electoral accountability, weaker } & 0.195 & & & & & 0.312 \\
\hline & $(0.77)$ & & & & & $(0.69)$ \\
\hline \multirow[t]{2}{*}{ Electoral accountability, int. } & $-4.122^{* * *}$ & & & & & 0.406 \\
\hline & $(-5.79)$ & & & & & $(0.42)$ \\
\hline \multirow[t]{2}{*}{ Legislative constraints, stronger } & & $1.425^{* * *}$ & & & & 0.794 \\
\hline & & $(4.58)$ & & & & $(1.57)$ \\
\hline \multirow[t]{2}{*}{ Legislative constraints, weaker } & & $1.116^{* * *}$ & & & & $2.334^{* * *}$ \\
\hline & & $(3.82)$ & & & & $(3.74)$ \\
\hline \multirow[t]{2}{*}{ Legislative constraints, int. } & & $-4.492^{* * *}$ & & & & -1.600 \\
\hline & & $(-7.90)$ & & & & $(-1.61)$ \\
\hline \multirow[t]{2}{*}{ Judicial constraints, stronger } & & & $1.681^{* * *}$ & & & 0.782 \\
\hline & & & $(4.00)$ & & & $(1.31)$ \\
\hline \multirow[t]{2}{*}{ Judicial constraints, weaker } & & & $0.815^{*}$ & & & -0.432 \\
\hline & & & $(2.40)$ & & & $(-0.95)$ \\
\hline \multirow[t]{2}{*}{ Judicial constraints, int. } & & & $-4.486^{* * *}$ & & & $-1.731^{*}$ \\
\hline & & & $(-6.86)$ & & & $(-2.15)$ \\
\hline \multirow[t]{2}{*}{ Media freedom, stronger } & & & & $1.328^{* * *}$ & & -0.922 \\
\hline & & & & $(4.40)$ & & $(-1.26)$ \\
\hline \multirow[t]{2}{*}{ Media freedom, weaker } & & & & $0.771^{* *}$ & & $-1.488^{*}$ \\
\hline & & & & $(2.85)$ & & $(-2.19)$ \\
\hline \multirow[t]{2}{*}{ Media freedom, int. } & & & & $-4.099^{* * *}$ & & 0.753 \\
\hline & & & & $(-7.66)$ & & $(0.74)$ \\
\hline \multirow[t]{2}{*}{ Civil society index, stronger } & & & & & $2.018^{* * *}$ & $1.670^{*}$ \\
\hline & & & & & $(4.64)$ & $(2.06)$ \\
\hline \multirow[t]{2}{*}{ Civil society index, weaker } & & & & & $1.401^{* * *}$ & 0.792 \\
\hline & & & & & $(3.69)$ & $(0.99)$ \\
\hline \multirow{2}{*}{ Civil society index, int. } & & & & & $-6.092^{* * *}$ & $-4.186^{* *}$ \\
\hline & & & & & $(-7.72)$ & $(-2.84)$ \\
\hline \multirow[t]{2}{*}{ Log CINC score, stronger } & 0.0502 & 0.0923 & 0.120 & 0.113 & 0.0803 & 0.110 \\
\hline & $(0.58)$ & $(1.01)$ & $(1.31)$ & $(1.20)$ & $(0.93)$ & $(1.16)$ \\
\hline \multirow[t]{2}{*}{ Loc CINC score, weaker } & $0.375^{* * *}$ & $0.370^{* * *}$ & $0.418^{* * *}$ & $0.346^{* * *}$ & $0.336^{* * *}$ & $0.325^{* * *}$ \\
\hline & $(4.34)$ & $(4.09)$ & $(4.40)$ & $(3.66)$ & $(3.71)$ & $(3.47)$ \\
\hline \multirow[t]{2}{*}{ Log population, stronger } & $0.199^{*}$ & 0.142 & 0.121 & 0.137 & 0.169 & 0.143 \\
\hline & $(2.04)$ & $(1.33)$ & $(1.08)$ & $(1.27)$ & (1.69) & $(1.19)$ \\
\hline \multirow[t]{2}{*}{ Log population, weaker } & 0.106 & 0.124 & 0.0515 & 0.146 & 0.159 & 0.149 \\
\hline & $(0.99)$ & $(1.07)$ & $(0.42)$ & $(1.21)$ & $(1.41)$ & $(1.30)$ \\
\hline Direct contiguity & $1.096^{* * *}$ & $1.032^{* * *}$ & $0.907^{* * *}$ & $1.040^{* * *}$ & $1.195^{* * *}$ & $0.956^{* * *}$ \\
\hline & $(4.54)$ & $(4.29)$ & $(3.72)$ & $(4.13)$ & $(4.90)$ & $(3.59)$ \\
\hline Log distance, ports & $-0.719^{* * *}$ & $-0.764^{* * *}$ & $-0.770^{* * *}$ & $-0.742^{* * *}$ & $-0.756^{* * * *}$ & $-0.790^{* * *}$ \\
\hline & $(-8.50)$ & $(-8.66)$ & $(-8.96)$ & $(-8.71)$ & $(-8.77)$ & $(-9.15)$ \\
\hline Log system size & $-0.637^{* * *}$ & $-0.658^{* * *}$ & $-0.744^{* * *}$ & $-0.659^{* * *}$ & $-0.533^{* * *}$ & $-0.688^{* * *}$ \\
\hline & $(-4.18)$ & $(-4.49)$ & $(-5.21)$ & $(-4.26)$ & $(-3.68)$ & $(-4.26)$ \\
\hline Peace years & $2.437^{* * *}$ & $2.474^{* * *}$ & $2.431^{* * *}$ & $2.450^{* * *}$ & $2.435^{* * *}$ & $2.389^{* * *}$ \\
\hline & $(17.01)$ & $(17.21)$ & $(17.29)$ & $(17.32)$ & $(17.18)$ & (17.09) \\
\hline Constant & -3.562 & -2.683 & -0.455 & -2.918 & -4.227 & -3.009 \\
\hline & $(-1.71)$ & $(-1.04)$ & $(-0.16)$ & $(-1.09)$ & $(-1.86)$ & $(-1.06)$ \\
\hline Observations & 541560 & 541560 & 541560 & 541560 & 541560 & 541560 \\
\hline$A I C$ & 5945.7 & 5917.9 & 5882.2 & 5876.4 & 5854.5 & 5808.3 \\
\hline
\end{tabular}

$t$ statistics in parentheses

${ }^{*} p<0.05,{ }^{* *} p<0.01,{ }^{* * *} p<0.001$ 
Table A-2. Estimation results, models with the five indices of constraint entered separately (columns 1-5) and jointly (column 6). Reduced sample: for computational reasons, we removed at random 95\% of all the non-MID dyad years but retained all the MID dyad years.

\begin{tabular}{|c|c|c|c|c|c|c|}
\hline & $\begin{array}{l}1 \text { Electoral } \\
\text { accountability }\end{array}$ & $\begin{array}{l}2 \text { Legislative } \\
\text { constraints }\end{array}$ & $\begin{array}{l}3 \text { Judicial } \\
\text { constraints }\end{array}$ & $\begin{array}{l}4 \text { Media } \\
\text { freedom }\end{array}$ & $\begin{array}{l}5 \text { Civil society } \\
\text { index }\end{array}$ & $\begin{array}{l}6 \text { Joint } \\
\text { constraint }\end{array}$ \\
\hline \multicolumn{7}{|l|}{ mzfatal_new } \\
\hline \multirow{2}{*}{$\begin{array}{l}\text { Electoral accountability, } \\
\text { stronger }\end{array}$} & $0.592^{*}$ & & & & & -0.0836 \\
\hline & $(2.23)$ & & & & & $(-0.19)$ \\
\hline \multirow{2}{*}{$\begin{array}{l}\text { Electoral accountability, } \\
\text { weaker }\end{array}$} & 0.00416 & & & & & 0.0800 \\
\hline & $(0.02)$ & & & & & $(0.18)$ \\
\hline \multirow[t]{2}{*}{ Electoral accountability, int. } & $-3.827^{* * *}$ & & & & & 1.275 \\
\hline & $(-5.11)$ & & & & & $(1.23)$ \\
\hline \multirow{2}{*}{$\begin{array}{l}\text { Legislative constraints, } \\
\text { stronger }\end{array}$} & & $1.567^{* * *}$ & & & & 1.113 \\
\hline & & $(4.56)$ & & & & $(1.92)$ \\
\hline \multirow{2}{*}{$\begin{array}{l}\text { Legislative constraints, } \\
\text { weaker }\end{array}$} & & $1.120^{* * * *}$ & & & & $2.556^{* * *}$ \\
\hline & & $(3.42)$ & & & & $(4.06)$ \\
\hline \multirow{2}{*}{ Legislative constraints, int. } & & $-4.930^{* * *}$ & & & & $-2.405^{*}$ \\
\hline & & $(-7.40)$ & & & & $(-2.25)$ \\
\hline \multirow[t]{2}{*}{ Judicial constraints, stronger } & & & $1.690^{* * *}$ & & & 0.767 \\
\hline & & & $(3.84)$ & & & $(1.21)$ \\
\hline \multirow[t]{2}{*}{ Judicial constraints, weaker } & & & 0.694 & & & -0.487 \\
\hline & & & $(1.82)$ & & & $(-0.93)$ \\
\hline \multirow[t]{2}{*}{ Judicial constraints, int. } & & & $-4.775^{* * *}$ & & & $-2.022^{*}$ \\
\hline & & & $(-6.47)$ & & & $(-2.23)$ \\
\hline \multirow[t]{2}{*}{ Media freedom, stronger } & & & & $1.319^{* * *}$ & & -0.911 \\
\hline & & & & $(3.79)$ & & $(-1.18)$ \\
\hline \multirow[t]{2}{*}{ Media freedom, weaker } & & & & $0.674^{*}$ & & -1.173 \\
\hline & & & & $(2.09)$ & & $(-1.63)$ \\
\hline \multirow[t]{2}{*}{ Media freedom, int. } & & & & $-4.245^{* * *}$ & & 0.237 \\
\hline & & & & $(-6.81)$ & & $(0.22)$ \\
\hline \multirow[t]{2}{*}{ Civil society index, stronger } & & & & & $2.052^{* * *}$ & $1.668^{*}$ \\
\hline & & & & & $(4.48)$ & $(2.17)$ \\
\hline \multirow[t]{2}{*}{ Civil society index, weaker } & & & & & $1.292^{* *}$ & 0.545 \\
\hline & & & & & $(3.17)$ & $(0.66)$ \\
\hline \multirow[t]{2}{*}{ Civil society index, int. } & & & & & $-6.233^{* * *}$ & $-3.652^{*}$ \\
\hline & & & & & $(-7.09)$ & $(-2.44)$ \\
\hline \multirow[t]{2}{*}{ Log CINC score, stronger } & 0.102 & 0.140 & 0.165 & 0.157 & 0.0960 & 0.131 \\
\hline & $(1.13)$ & $(1.58)$ & $(1.86)$ & $(1.71)$ & $(1.10)$ & $(1.40)$ \\
\hline \multirow[t]{2}{*}{ Loc CINC score, weaker } & $0.378^{* * *}$ & $0.370^{* * *}$ & $0.455^{* * *}$ & $0.360^{* * *}$ & $0.329^{* * *}$ & $0.356^{* * *}$ \\
\hline & $(4.06)$ & $(4.09)$ & $(4.86)$ & $(3.87)$ & $(3.64)$ & $(3.75)$ \\
\hline \multirow[t]{2}{*}{ Log population, stronger } & 0.167 & 0.107 & 0.103 & 0.111 & 0.170 & 0.145 \\
\hline & $(1.62)$ & $(1.07)$ & $(0.99)$ & $(1.06)$ & $(1.68)$ & $(1.25)$ \\
\hline \multirow[t]{2}{*}{ Log population, weaker } & 0.0907 & 0.109 & -0.0185 & 0.111 & 0.149 & 0.0862 \\
\hline & $(0.80)$ & $(0.98)$ & $(-0.16)$ & $(0.97)$ & $(1.33)$ & $(0.74)$ \\
\hline Direct contiguity & $1.093^{* * *}$ & $1.041^{* * *}$ & $0.873^{* * *}$ & $1.025^{* * *}$ & $1.182^{* * *}$ & $0.933^{* *}$ \\
\hline & $(4.31)$ & $(4.13)$ & $(3.48)$ & $(3.91)$ & $(4.55)$ & $(3.29)$ \\
\hline Log distance, ports & $-0.782^{* * *}$ & $-0.816^{* * *}$ & $-0.850^{* * *}$ & $-0.798^{* * *}$ & $-0.809^{* * *}$ & $-0.855^{* * *}$ \\
\hline & $(-9.28)$ & $(-9.78)$ & $(-10.40)$ & $(-9.46)$ & $(-9.72)$ & $(-10.29)$ \\
\hline Log system size & $-0.607^{* * *}$ & $-0.653^{* * *}$ & $-0.741^{* * *}$ & $-0.658^{* * *}$ & $-0.531^{* * *}$ & $-0.713^{* * *}$ \\
\hline & $(-3.75)$ & $(-4.30)$ & $(-4.97)$ & $(-4.06)$ & $(-3.39)$ & $(-4.12)$ \\
\hline Peace years & $2.101^{* * *}$ & $2.088^{* * *}$ & $2.069^{* * *}$ & $2.108^{* * *}$ & $2.076^{* * *}$ & $2.048^{* * *}$ \\
\hline & $(10.96)$ & $(11.34)$ & $(11.71)$ & $(11.75)$ & $(11.40)$ & $(11.36)$ \\
\hline Constant & 1.023 & 1.828 & $5.172^{*}$ & 1.915 & -0.561 & 1.793 \\
\hline & $(0.42)$ & $(0.78)$ & $(2.12)$ & $(0.79)$ & $(-0.24)$ & $(0.70)$ \\
\hline Observations & 27547 & 27547 & 27547 & 27547 & 27547 & 27547 \\
\hline$A I C$ & 3133.9 & 3096.5 & 3060.5 & 3062.8 & 3050.9 & 3007.4 \\
\hline
\end{tabular}

$t$ statistics in parentheses

${ }^{*} p<0.05,{ }^{* *} p<0.01,{ }^{* * *} p<0.001$ 
Table A-3. Estimation results, models estimated to assess robustness. Reduced sample.

\begin{tabular}{|c|c|c|c|}
\hline & 13 Schumpeter & $\begin{array}{l}14 \text { Horizontal } \\
\text { constraints }\end{array}$ & $\begin{array}{l}15 \text { Lean civil } \\
\text { society }\end{array}$ \\
\hline \multicolumn{4}{|l|}{ mzfatal_new } \\
\hline Schumpeterian accountability, stronger & $\begin{array}{l}0.449 \\
(1.77)\end{array}$ & & \\
\hline Schumpeterian accountability, weaker & $\begin{array}{l}-0.239 \\
(-0.92)\end{array}$ & & \\
\hline Schumpeterian accountability, int. & $\begin{array}{l}-3.919^{* * *} \\
(-5.50)\end{array}$ & & \\
\hline Suffrage, stronger & $\begin{array}{l}-0.871 \\
(-1.23)\end{array}$ & & \\
\hline Suffrage, weaker & $\begin{array}{l}-0.0997 \\
(-0.15)\end{array}$ & & \\
\hline Suffrage, interaction & $\begin{array}{l}1.273 \\
(1.57)\end{array}$ & & \\
\hline Executive constraints, stronger & & $\begin{array}{l}2.153^{* * *} \\
(4.94)\end{array}$ & \\
\hline Executive constraints, weaker & & $\begin{array}{l}1.297^{* * *} \\
(3.30)\end{array}$ & \\
\hline Executive constraints, int. & & $\begin{array}{l}-6.160^{* * *} \\
(-7.46)\end{array}$ & \\
\hline \multicolumn{4}{|l|}{ Media freedom, stronger } \\
\hline \multicolumn{4}{|l|}{ Media freedom, weaker } \\
\hline \multicolumn{4}{|l|}{ Media freedom, int. } \\
\hline \multicolumn{4}{|l|}{ Civil society index, stronger } \\
\hline \multicolumn{4}{|l|}{ Civil society index, weaker } \\
\hline \multicolumn{4}{|l|}{ Civil society index, int. } \\
\hline Lean civil society index, stronger & & & $\begin{array}{l}-0.0907^{*} \\
(-2.11)\end{array}$ \\
\hline Lean civil society index, weaker & & & $\begin{array}{l}-0.239^{* * *} \\
(-5.47)\end{array}$ \\
\hline Lean civil society index, int. & & & $\begin{array}{l}-0.143^{* * *} \\
(-5.42)\end{array}$ \\
\hline Log CINC score, stronger & $\begin{array}{l}0.179 \\
(1.91)\end{array}$ & $\begin{array}{l}0.143 \\
(1.61)\end{array}$ & $\begin{array}{l}0.0900 \\
(0.99)\end{array}$ \\
\hline Loc CINC score, weaker & $\begin{array}{l}0.451^{* * *} \\
(4.51)\end{array}$ & $\begin{array}{l}0.429^{* * *} \\
(4.69)\end{array}$ & $\begin{array}{l}0.293^{* *} \\
(3.11)\end{array}$ \\
\hline Log population, stronger & $\begin{array}{l}0.0843 \\
(0.79)\end{array}$ & $\begin{array}{l}0.109 \\
(1.07)\end{array}$ & $\begin{array}{l}0.166 \\
(1.61)\end{array}$ \\
\hline Log population, weaker & $\begin{array}{l}-0.0138 \\
(-0.11)\end{array}$ & $\begin{array}{l}0.0240 \\
(0.21)\end{array}$ & $\begin{array}{l}0.188 \\
(1.63)\end{array}$ \\
\hline Direct contiguity & $\begin{array}{l}0.993^{* * *} \\
(3.69)\end{array}$ & $\begin{array}{l}0.948^{* * *} \\
(3.74)\end{array}$ & $\begin{array}{l}0.988^{* * *} \\
(3.74)\end{array}$ \\
\hline Log distance, ports & $\begin{array}{l}-0.769^{* * *} \\
(-9.17)\end{array}$ & $\begin{array}{l}-0.840^{* * *} \\
(-10.30)\end{array}$ & $\begin{array}{l}-0.788^{* * *} \\
(-9.20)\end{array}$ \\
\hline Log system size & $\begin{array}{l}-0.703^{* * *} \\
(-4.13)\end{array}$ & $\begin{array}{l}-0.719^{* * *} \\
(-4.79)\end{array}$ & $\begin{array}{l}-0.690^{* * *} \\
(-4.45)\end{array}$ \\
\hline Peace years & $\begin{array}{l}2.089^{* * *} \\
(11.16)\end{array}$ & $\begin{array}{l}2.071^{* * *} \\
(11.70)\end{array}$ & $\begin{array}{l}2.104^{* * *} \\
(11.82)\end{array}$ \\
\hline Constant & $\begin{array}{l}4.912 \\
(1.85) \\
\end{array}$ & $\begin{array}{l}3.731 \\
(1.58)\end{array}$ & $\begin{array}{l}-1.108 \\
(-0.46)\end{array}$ \\
\hline $\begin{array}{l}\text { Observations } \\
\text { AIC }\end{array}$ & $\begin{array}{l}27547 \\
3106.3\end{array}$ & $\begin{array}{l}27547 \\
3053.4\end{array}$ & $\begin{array}{l}27547 \\
3113.1\end{array}$ \\
\hline
\end{tabular}

$t$ statistics in parentheses

${ }^{*} p<0.05,{ }^{* *} p<0.01,{ }^{* * *} p<0.001$ 
Table A-4. Estimation results, models using Polity and the five standard V-Dem indices of democracy entered separately (columns 1-5). Reduced sample.

\begin{tabular}{|c|c|c|c|c|c|c|}
\hline & 7 Polity & 8 Polyarchy & $\begin{array}{l}9 \text { Liberal } \\
\text { democracy }\end{array}$ & $\begin{array}{l}10 \text { Participatory } \\
\text { democracy }\end{array}$ & $\begin{array}{l}11 \text { Deliberative } \\
\text { democracy }\end{array}$ & $\begin{array}{l}12 \text { Egalitarian } \\
\text { democracy }\end{array}$ \\
\hline \multicolumn{7}{|l|}{ mzfatal new } \\
\hline Polity score, stronger & $\begin{array}{l}-0.0347^{* * *} \\
(-3.35)\end{array}$ & & & & & \\
\hline Polity score, weaker & $\begin{array}{l}-0.0605^{* * *} \\
(-5.56)\end{array}$ & & & & & \\
\hline Polity score, interaction & $\begin{array}{l}-0.00874^{* * *} \\
(-6.44)\end{array}$ & & & & & \\
\hline Polyarchy index, stronger & & $\begin{array}{l}1.578^{* * *} \\
(3.72)\end{array}$ & & & & \\
\hline Polyarchy index, weaker & & $\begin{array}{l}0.830^{*} \\
(2.01)\end{array}$ & & & & \\
\hline Polyarchy index, interaction & & $\begin{array}{l}-6.664^{* * *} \\
(-5.81)\end{array}$ & & & & \\
\hline HLI liberal index, stronger & & & $\begin{array}{l}1.765^{* * *} \\
(3.96)\end{array}$ & & & \\
\hline HLI liberal index, weaker & & & $\begin{array}{l}0.735 \\
(1.78)\end{array}$ & & & \\
\hline HLI liberal index, interaction & & & $\begin{array}{l}-10.95^{* * *} \\
(-5.25)\end{array}$ & & & \\
\hline HLI participatory index, stronger & & & & $\begin{array}{l}1.809^{* *} \\
(3.25)\end{array}$ & & \\
\hline HLI participatory index, weaker & & & & $\begin{array}{l}0.716 \\
(1.41)\end{array}$ & & \\
\hline HLI participatory index, interaction & & & & $\begin{array}{l}-13.66^{* * *} \\
(-5.45)\end{array}$ & & \\
\hline HLI deliberative index, stronger & & & & & $\begin{array}{l}1.035^{* *} \\
(2.93)\end{array}$ & \\
\hline HLI deliberative index, weaker & & & & & $\begin{array}{l}0.221 \\
(0.66)\end{array}$ & \\
\hline HLI deliberative index, interaction & & & & & $\begin{array}{l}-8.163^{* * *} \\
(-5.17)\end{array}$ & \\
\hline HLI egalitarian index, stronger & & & & & & $\begin{array}{l}1.769^{* * *} \\
(3.41)\end{array}$ \\
\hline HLI egalitarian index, weaker & & & & & & $\begin{array}{l}0.788 \\
(1.53)\end{array}$ \\
\hline HLI egalitarian index, interaction & & & & & & $\begin{array}{l}-9.797^{* * *} \\
(-5.31)\end{array}$ \\
\hline Log CINC score, stronger & $\begin{array}{l}0.154 \\
(1.71)\end{array}$ & $\begin{array}{l}0.141 \\
(1.58)\end{array}$ & $\begin{array}{l}0.135 \\
(1.51)\end{array}$ & $\begin{array}{l}0.130 \\
(1.47)\end{array}$ & $\begin{array}{l}0.128 \\
(1.43)\end{array}$ & $\begin{array}{l}0.162 \\
(1.70)\end{array}$ \\
\hline Loc CINC score, weaker & $\begin{array}{l}0.373^{* * *} \\
(4.23)\end{array}$ & $\begin{array}{l}0.367^{* * *} \\
(4.11)\end{array}$ & $\begin{array}{l}0.416^{* * *} \\
(4.58)\end{array}$ & $\begin{array}{l}0.378^{* * *} \\
(4.21)\end{array}$ & $\begin{array}{l}0.391^{* * *} \\
(4.27)\end{array}$ & $\begin{array}{l}0.436^{* * *} \\
(4.54)\end{array}$ \\
\hline Log population, stronger & $\begin{array}{l}0.117 \\
(1.13)\end{array}$ & $\begin{array}{l}0.122 \\
(1.20)\end{array}$ & $\begin{array}{l}0.127 \\
(1.22)\end{array}$ & $\begin{array}{l}0.134 \\
(1.31)\end{array}$ & $\begin{array}{l}0.142 \\
(1.38)\end{array}$ & $\begin{array}{l}0.124 \\
(1.15)\end{array}$ \\
\hline Log population, weaker & $\begin{array}{l}0.109 \\
(0.99)\end{array}$ & $\begin{array}{l}0.108 \\
(0.98)\end{array}$ & $\begin{array}{l}0.0432 \\
(0.39)\end{array}$ & $\begin{array}{l}0.0974 \\
(0.89)\end{array}$ & $\begin{array}{l}0.0847 \\
(0.75)\end{array}$ & $\begin{array}{l}0.0321 \\
(0.28)\end{array}$ \\
\hline Direct contiguity & $\begin{array}{l}1.098^{* * *} \\
(4.30)\end{array}$ & $\begin{array}{l}1.148^{* * *} \\
(4.62)\end{array}$ & $\begin{array}{l}1.083^{* * *} \\
(4.33)\end{array}$ & $\begin{array}{l}1.138^{* * *} \\
(4.55)\end{array}$ & $\begin{array}{l}1.161^{* * *} \\
(4.63)\end{array}$ & $\begin{array}{l}1.193^{* * *} \\
(4.71)\end{array}$ \\
\hline Log distance, ports & $\begin{array}{l}-0.793^{* * *} \\
(-9.44)\end{array}$ & $\begin{array}{l}-0.810^{* * *} \\
(-9.56)\end{array}$ & $\begin{array}{l}-0.835^{* * *} \\
(-10.06)\end{array}$ & $\begin{array}{l}-0.812^{* * *} \\
(-9.77)\end{array}$ & $\begin{array}{l}-0.797^{* * *} \\
(-9.54)\end{array}$ & $\begin{array}{l}-0.849^{* * *} \\
(-9.91)\end{array}$ \\
\hline Log system size & $\begin{array}{l}-0.616^{* * *} \\
(-3.87)\end{array}$ & $\begin{array}{l}-0.532^{* * *} \\
(-3.39)\end{array}$ & $\begin{array}{l}-0.587^{* * *} \\
(-3.81)\end{array}$ & $\begin{array}{l}-0.534^{* * *} \\
(-3.46)\end{array}$ & $\begin{array}{l}-0.545^{* * *} \\
(-3.48)\end{array}$ & $\begin{array}{l}-0.458^{* *} \\
(-2.81)\end{array}$ \\
\hline Peace years & $\begin{array}{l}2.144^{* * *} \\
(11.44)\end{array}$ & $\begin{array}{l}2.092^{* * *} \\
(11.03)\end{array}$ & $\begin{array}{l}2.066^{* * *} \\
(11.17)\end{array}$ & $\begin{array}{l}2.052^{* * *} \\
(11.07)\end{array}$ & $\begin{array}{l}2.063^{* * *} \\
(10.88)\end{array}$ & $\begin{array}{l}2.053^{* * *} \\
(10.48)\end{array}$ \\
\hline Constant & $\begin{array}{l}1.714 \\
(0.74)\end{array}$ & $\begin{array}{l}1.652 \\
(0.69)\end{array}$ & $\begin{array}{l}3.197 \\
(1.36)\end{array}$ & $\begin{array}{l}1.756 \\
(0.74)\end{array}$ & $\begin{array}{l}1.830 \\
(0.78)\end{array}$ & $\begin{array}{l}3.658 \\
(1.49)\end{array}$ \\
\hline Observations & 27547 & 27547 & 27547 & 27547 & 27547 & 27547 \\
\hline$A I C$ & 3080.6 & 3084.6 & 3048.9 & 3080.9 & 3082.6 & 3089.4 \\
\hline
\end{tabular}


Table A-5. Estimation results, models using traditional 'weak-link' construction. Full sample

\begin{tabular}{|c|c|c|c|c|c|c|}
\hline & $\begin{array}{c}1 \text { Electoral } \\
\text { accountability }\end{array}$ & $\begin{array}{l}2 \text { Legislative } \\
\text { constraints }\end{array}$ & $\begin{array}{l}3 \text { Judicial } \\
\text { constraints }\end{array}$ & $\begin{array}{l}4 \text { Media } \\
\text { freedom) }\end{array}$ & $\begin{array}{c}5 \text { Civil } \\
\text { society index }\end{array}$ & $\begin{array}{c}6 \text { Joint } \\
\text { constraint }\end{array}$ \\
\hline \multicolumn{7}{|l|}{ mzfatal_new } \\
\hline Electoral accountability lower & $\begin{array}{c}-2.949^{* * *} \\
(-6.46)\end{array}$ & & & & & $\begin{array}{l}-0.399 \\
(-0.69)\end{array}$ \\
\hline Electoral accountability higher & $\begin{array}{l}0.412^{*} \\
(2.27)\end{array}$ & & & & & $\begin{array}{l}0.232 \\
(0.78)\end{array}$ \\
\hline Legislative constraints lower & & $\begin{array}{c}-2.261^{* * *} \\
(-7.55)\end{array}$ & & & & $\begin{array}{l}0.691 \\
(1.45)\end{array}$ \\
\hline Legislative constraints higher & & $\begin{array}{l}0.768^{* * * *} \\
(3.29)\end{array}$ & & & & $\begin{array}{l}1.340^{* * *} \\
(3.08)\end{array}$ \\
\hline Judicial constraints lower & & & $\begin{array}{c}-2.310^{* * *} \\
(-7.40)\end{array}$ & & & $\begin{array}{l}-1.187^{* * *} \\
(-3.02)\end{array}$ \\
\hline Judicial contraints higher & & & $\begin{array}{l}0.554^{*} \\
(2.02)\end{array}$ & & & $\begin{array}{l}-0.119 \\
(-0.28)\end{array}$ \\
\hline Media freedom lower & & & & $\begin{array}{c}-2.275^{* * *} \\
(-7.92)\end{array}$ & & $\begin{array}{l}-0.170 \\
(-0.29)\end{array}$ \\
\hline Media freedom higher & & & & $\begin{array}{l}0.478^{*} \\
(2.24)\end{array}$ & & $\begin{array}{l}-1.039 \\
(-1.85)\end{array}$ \\
\hline Civil society index lower & & & & & $\begin{array}{c}-3.200^{* * *} \\
(-9.64)\end{array}$ & $\begin{array}{c}-2.500^{* * *} \\
(-3.42)\end{array}$ \\
\hline Civil society index higher & & & & & $\begin{array}{l}0.860^{* * * *} \\
(3.30)\end{array}$ & $\begin{array}{l}0.544 \\
(1.04)\end{array}$ \\
\hline Log CINC score, stronger & $\begin{array}{l}0.0973 \\
(1.02)\end{array}$ & $\begin{array}{l}0.0941 \\
(0.97)\end{array}$ & $\begin{array}{l}0.123 \\
(1.25)\end{array}$ & $\begin{array}{l}0.0915 \\
(0.94)\end{array}$ & $\begin{array}{l}0.0762 \\
(0.83)\end{array}$ & $\begin{array}{l}0.0823 \\
(0.89)\end{array}$ \\
\hline Loc CINC score, weaker & $\begin{array}{l}0.321^{* * *} \\
(3.66)\end{array}$ & $\begin{array}{l}0.321^{* * * *} \\
(3.56)\end{array}$ & $\begin{array}{l}0.333^{* * *} \\
(3.49)\end{array}$ & $\begin{array}{l}0.295^{* *} \\
(3.09)\end{array}$ & $\begin{array}{l}0.255^{* *} \\
(2.81)\end{array}$ & $\begin{array}{l}0.266^{* *} \\
(2.93)\end{array}$ \\
\hline Log population, stronger & $\begin{array}{l}0.148 \\
(1.43)\end{array}$ & $\begin{array}{l}0.125 \\
(1.14)\end{array}$ & $\begin{array}{l}0.0872 \\
(0.73)\end{array}$ & $\begin{array}{l}0.148 \\
(1.33)\end{array}$ & $\begin{array}{l}0.162 \\
(1.54)\end{array}$ & $\begin{array}{l}0.142 \\
(1.27)\end{array}$ \\
\hline Log population, weaker & $\begin{array}{l}0.169 \\
(1.57)\end{array}$ & $\begin{array}{l}0.179 \\
(1.52)\end{array}$ & $\begin{array}{l}0.154 \\
(1.22)\end{array}$ & $\begin{array}{l}0.201 \\
(1.63)\end{array}$ & $\begin{array}{l}0.251^{*} \\
(2.18)\end{array}$ & $\begin{array}{l}0.232^{*} \\
(2.05)\end{array}$ \\
\hline Direct contiguity & $\begin{array}{l}1.103^{* * *} \\
(4.54)\end{array}$ & $\begin{array}{l}0.999^{* * * *} \\
(4.07)\end{array}$ & $\begin{array}{l}0.898^{* * * *} \\
(3.54)\end{array}$ & $\begin{array}{c}0.972^{* * *} \\
(3.75)\end{array}$ & $\begin{array}{l}1.121^{* * * *} \\
(4.46)\end{array}$ & $\begin{array}{l}0.978^{* * *} \\
(3.65)\end{array}$ \\
\hline Log distance, ports & $\begin{array}{c}-0.735^{* * *} \\
(-8.71)\end{array}$ & $\begin{array}{c}-0.758^{* * *} \\
(-8.62)\end{array}$ & $\begin{array}{c}-0.757^{* * *} \\
(-8.32)\end{array}$ & $\begin{array}{c}-0.746^{* * *} \\
(-8.85)\end{array}$ & $\begin{array}{c}-0.772^{* * *} \\
(-8.88)\end{array}$ & $\begin{array}{c}-0.783^{* * *} \\
(-8.84)\end{array}$ \\
\hline Log system size & $\begin{array}{c}-0.619^{* * *} \\
(-3.95)\end{array}$ & $\begin{array}{c}-0.682^{* * *} \\
(-4.44)\end{array}$ & $\begin{array}{c}-0.751^{* * *} \\
(-4.99)\end{array}$ & $\begin{array}{c}-0.694^{* * *} \\
(-4.18)\end{array}$ & $\begin{array}{c}-0.569^{* * *} \\
(-3.70)\end{array}$ & $\begin{array}{c}-0.670^{* * * *} \\
(-4.06)\end{array}$ \\
\hline $\begin{array}{l}\text { Peace years } \\
\text { Constant }\end{array}$ & $\begin{array}{c}2.450^{* * * *} \\
(17.02) \\
-3.643\end{array}$ & $\begin{array}{l}2.492^{* * *} \\
(17.10) \\
-3.210\end{array}$ & $\begin{array}{c}2.472^{* * * *} \\
(16.64) \\
-1.581\end{array}$ & $\begin{array}{c}2.472^{* * *} \\
(16.98) \\
-3.886\end{array}$ & $\begin{array}{l}2.474^{* * *} \\
(16.97) \\
-5.200^{*}\end{array}$ & $\begin{array}{c}2.427^{* * *} \\
(16.72) \\
-4.140\end{array}$ \\
\hline & $(-1.71)$ & $(-1.24)$ & $(-0.53)$ & $(-1.44)$ & $(-2.19)$ & $(-1.55)$ \\
\hline$N$ & 541560 & 541560 & 541560 & 541560 & 541560 & 541560 \\
\hline AIC & 5942.3 & 5941.9 & 5922.2 & 5909.0 & 5874.2 & 5845.5 \\
\hline
\end{tabular}

